\title{
O índio na fotografia brasileira: incursões sobre a imagem e o meio
}

\author{
The Indian in Brazilian photography: incursions \\ into image and medium
}

\section{Fernando de Tacca}

Professor da Universidade Estadual de Campinas; editor da revista Studium.

Rua Eça de Queiroz, 403 13075-240 - Campinas - SP - Brasil tacca@unicamp.br
TACCA, Fernando de. O índio na fotografia brasileira: incursões sobre a imagem e o meio. História, Ciências, Saúde - Manguinhos, Rio de Janeiro, v.18, n.1, jan.-mar. 2011, p.191-223.

\section{Resumo}

Pretende-se explorar contradições e confluências entre o meio (fotográfico) e a imagem do índio brasileiro sob uma perspectiva histórica da fotografia brasileira. A imagem do índio nessa fotografia manifesta-se em três momentos distintos. Na fase inicial, no lugar do exótico, contraditório ao sentido moderno da fotografia durante o Segundo Império. Na segunda fase, as fronteiras entre o etnográfico e o nacional se diluem, nos primeiros cinquenta anos do século XX, a exemplo da Comissão Rondon/Seção de Estudos do SPI e do fotojornalismo moderno no Brasil da revista O Cruzeiro. No terceiro momento, as manifestações de uma etnopoética das fotografias de Claudia Andujar fazem meio e imagem se fundirem como lugar etnográfico na arte contemporânea.

Palavras-chaves: fotografia; índio brasileiro; antropologia visual; fotojornalismo; Claudia Andujar (1931-).

\section{Abstract}

The article explores contradictions and convergences between a medium (photography) and the image of the Brazilian Indian from the perspective of the history of Brazilian photography. During the first of three distinct moments, the image of the Indian was of someone exotic, in contradiction with the modern meaning of photography under the Second Empire. During the second moment, in the first fifty years of the twentieth century, the boundaries between ethnography and Brazil as a nation were blurred, as exemplified by the Rondon Commission/Indian Protection Bureau's Research Section (Serviço de Proteção ao Indio) and Brazil's modern photojournalism, as found in the magazine Cruzeiro. During the third moment, the expressions of an ethno-poetry present in the photographs of Cláudia Andujar can be seen to blend medium and image as an ethnographic space in contemporary art.

Keywords: photography; Brazilian Indian; visual anthropology; photojournalism; Claudia Andujar (1931-). 


\section{O exótico distante e possibilidade etnográfica}

Ao nos debruçamos sobre um itinerário longo e permeado por inúmeras fotografias sobre indígenas brasileiros desde o século XIX aos dias de hoje, podemos cair na armadilha de uma generalização inconsistente. Sabendo de antemão das dificuldades de tal abordagem e reconhecendo lugares da circulação da imagem pelos quais o imaginário tem articulação e vibração intermitentes, ou seja, lugares nos quais as imagens são referenciadas e elevadas à condição simbólica, as escolhas se darão no campo de conjuntos importantes para a formação e alimentação imagética sobre a construção inicial de um olhar sobre o índio brasileiro como 'selvagem', considerando uma imagem de vivência tradicional, ou na sua condição de passagem para uma imagem civilizada, depois de 'pacificado'.

A primeira constatação é que o indígena tem uma representação muito pequena e quase imperceptível durante todo o século XIX. As primeiras imagens foram realizadas na França: é um conjunto de cinco daguerreótipos de índios então chamados Botocudo (pertencentes ao grupo linguístico Krenak). São imagens realizadas na França por E. Thiesson, pois os índios retratados foram levados àquele país, para serem apresentados em eventos científicos. Os cinco daguerreótipos de dois botocudo pertencem hoje ao acervo da Fototeca do Museu do Homem, em Paris. As fotografias pertenceram a uma galeria especial, formada em 1850 no antigo Museu de História Natural de Paris, na qual havia reproduções de partes do corpo humano, esqueletos, objetos; enfim, elementos da antropologia física que serviram de base para estudos comparativos. Segundo Marco Morel (2002), "a presença desses 'selvagens' causou ebulição no meio intelectual parisiense. Foram tema de relatórios e acalorados debates na sessão de verão da Academia de Paris em 1843. Depois da discussão acadêmica, a decodificação: apalpados, medidos e enquadrados nos cânones do discurso institucional da antropologia física, além de registrados pela Sociedade de Geografia".

Somente vinte anos depois, na década de 1860, houve novas imagens. Bartolomé Bossi, italiano emigrado para Argentina, fez uma incursão fotográfica em 1860 na província de Mato Grosso, que resultou no livro Viaje pitoresco (Paris, 1863), dedicado ao barão de Mauá. As xilografias da obra são de Lacoste Ainé, a partir das fotografias de Bossi. As imagens dialogam com a estética do desenho, no qual a fotografia é parte do palimpsesto, uma camada invisível mas decifrável. Algumas fotografias foram apresentadas na Exposição de História do Brasil, em 1881 (Kossoy, 2002).

Muito referenciadas e presentes em várias publicações sobre a fotografia brasileira, duas imagens de A. Frisch (Albert, segundo historiadores; pouco se sabe sobre ele nos escritos sobre a fotografia do século XIX) foram realizadas nos arredores de Manaus em 1865 e são as primeiras imagens que transmitem uma ideia do habitat, por serem feitas ao ar livre, provavelmente já utilizando placas secas (albume), ou então carregando um pesado equipamento para revelação de placas úmidas, o que seria muito difícil nas condições amazônicas. Os índios tiveram de ficar posando, sem se mexer, para que não surgissem como figuras em borrão fantasmagórico, e as condições materiais de sua existência são apresentadas como a casa e floresta circundante. Dos daguerreótipos europeus à floresta temos um salto de conteúdo, no qual o etnográfico incorpora contexto e cultura e não os deslocamentos espaciais da casa ao estúdio; assim, os índios passam a estar em seu habitat. 
Segundo Kossoy (2002, p.149), as fotos provavelmente foram encomendadas pela Casa Leuzinger e algumas delas foram apresentadas na Exposição Universal de Paris, em 1887, ocasião em que receberam menção honrosa.

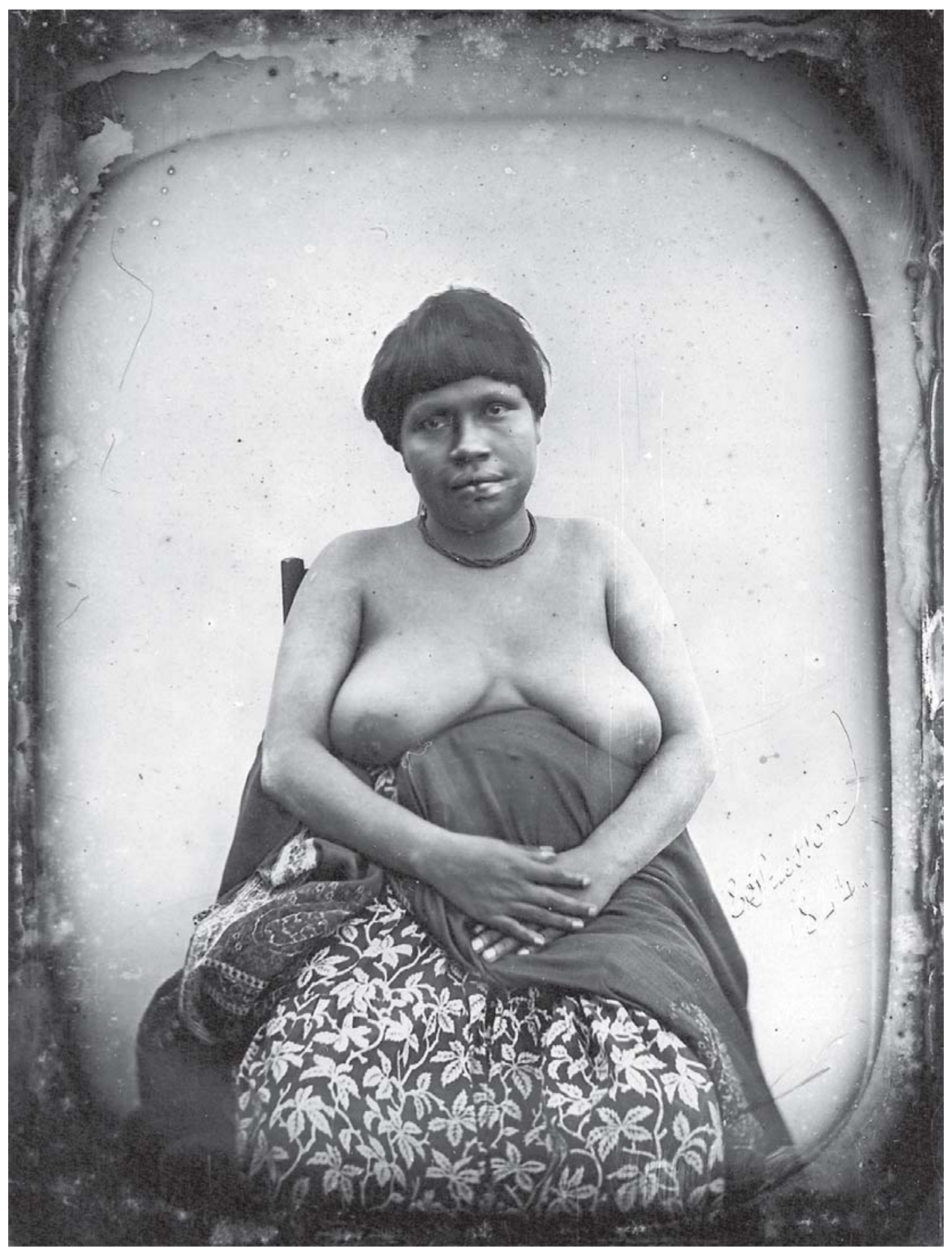

Figura 1: Índios botocudo, 1843, daguerreótipo de E. Thiesson (Musée de I'Homme) 


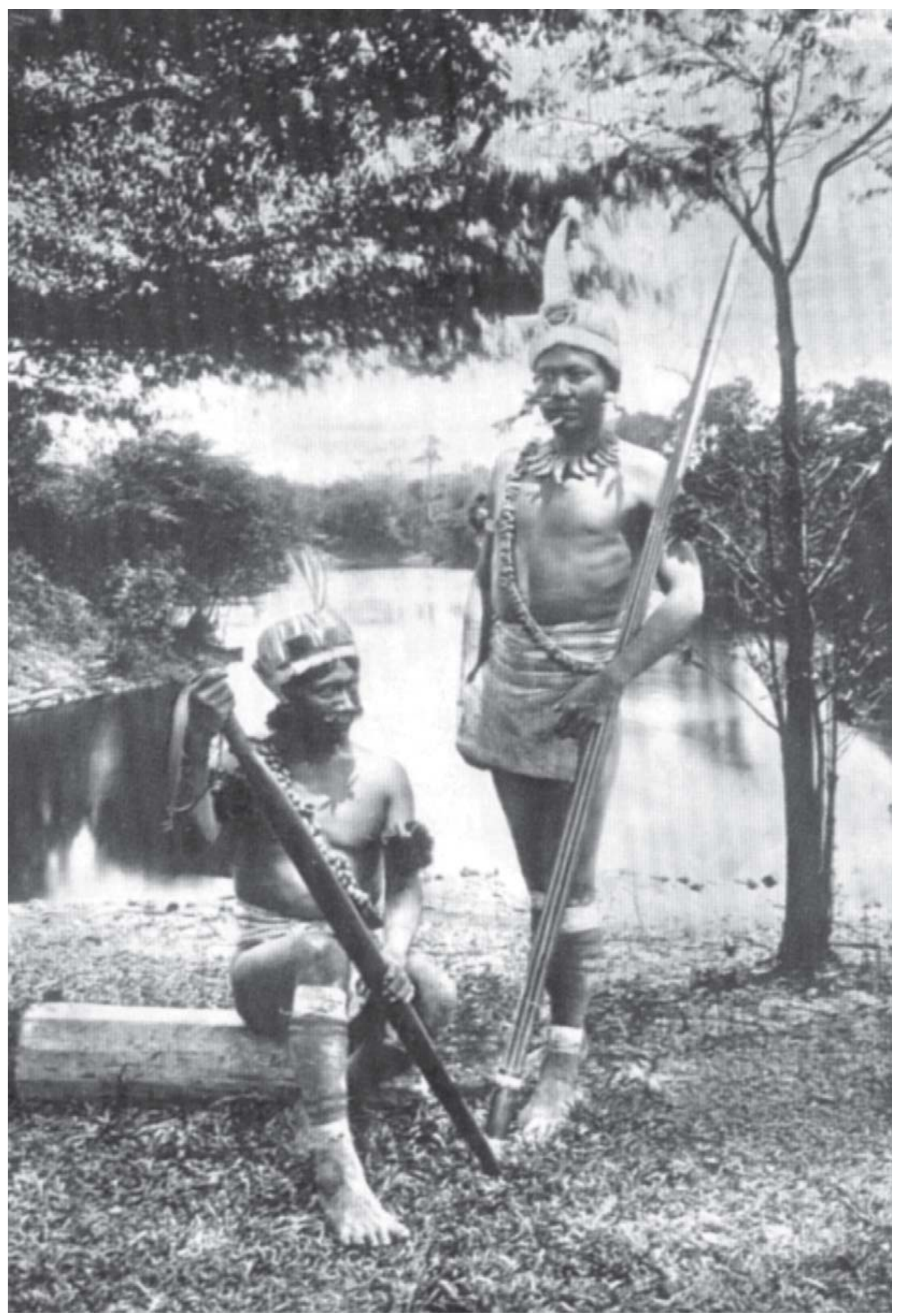

Figura 2: Índios amua do Alto Amazonas, Manaus, 1865, foto de A. Frisch (Biblioteca Nacional) 


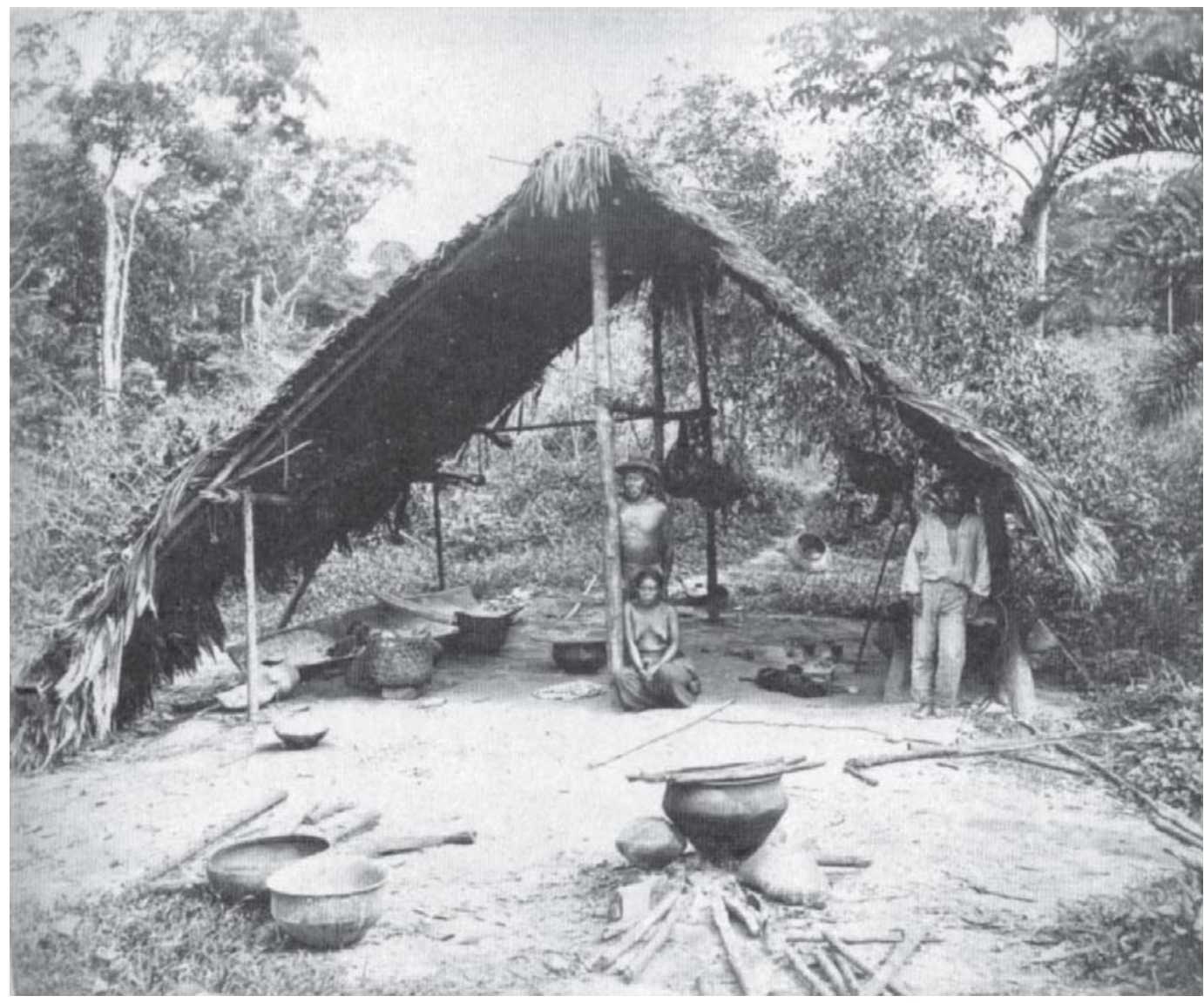

Figura 3: A cozinha da maloca, Manaus, 1865, foto de A. Frisch (Biblioteca Nacional)

Como condição especial, algumas fotografias ganham relevância pelo autor das mesmas por uma assinatura indelével. Assim, as imagens produzidas por um dos mais importantes fotógrafos brasileiros do século XIX, Marc Ferrez, são parte significativa do conjunto da época. Integrando, como fotógrafo, a Comissão Geológica do Império, sob comando do geógrafo e geólogo Charles Frederick Hartt, Ferrez também fotografou os conhecidos Botocudo, na Bahia. A tentativa de uma antropometria, visível nas imagens de Ferrez, demonstra o que poderia ser uma primeira inserção da fotografia de índios nas expedições científicas: um objeto a ser mensurado e dominado, tal como a natureza representada em mapas.

Marc Ferrez apresentou uma série de imagens de objetos, retratos e elementos da vida indígena na Exposição Antropológica Brasileira, no Museu Nacional, em 1882. Provavelmente essas imagens fizeram parte dos álbuns comercializados para estrangeiros, pelo seu caráter exótico. O importante a salientar é que, a despeito da grande importância da fotografia no Segundo Império e sendo o imperador um incentivador de suas práticas, as fotografias de povos indígenas não tiveram efetiva presença e são quase inexpressivas no conjunto geral do período, a exemplo da pouca presença delas na coleção imperial e em citações no Dicionário histórico fotográfico brasileiro, de Boris Kossoy. 


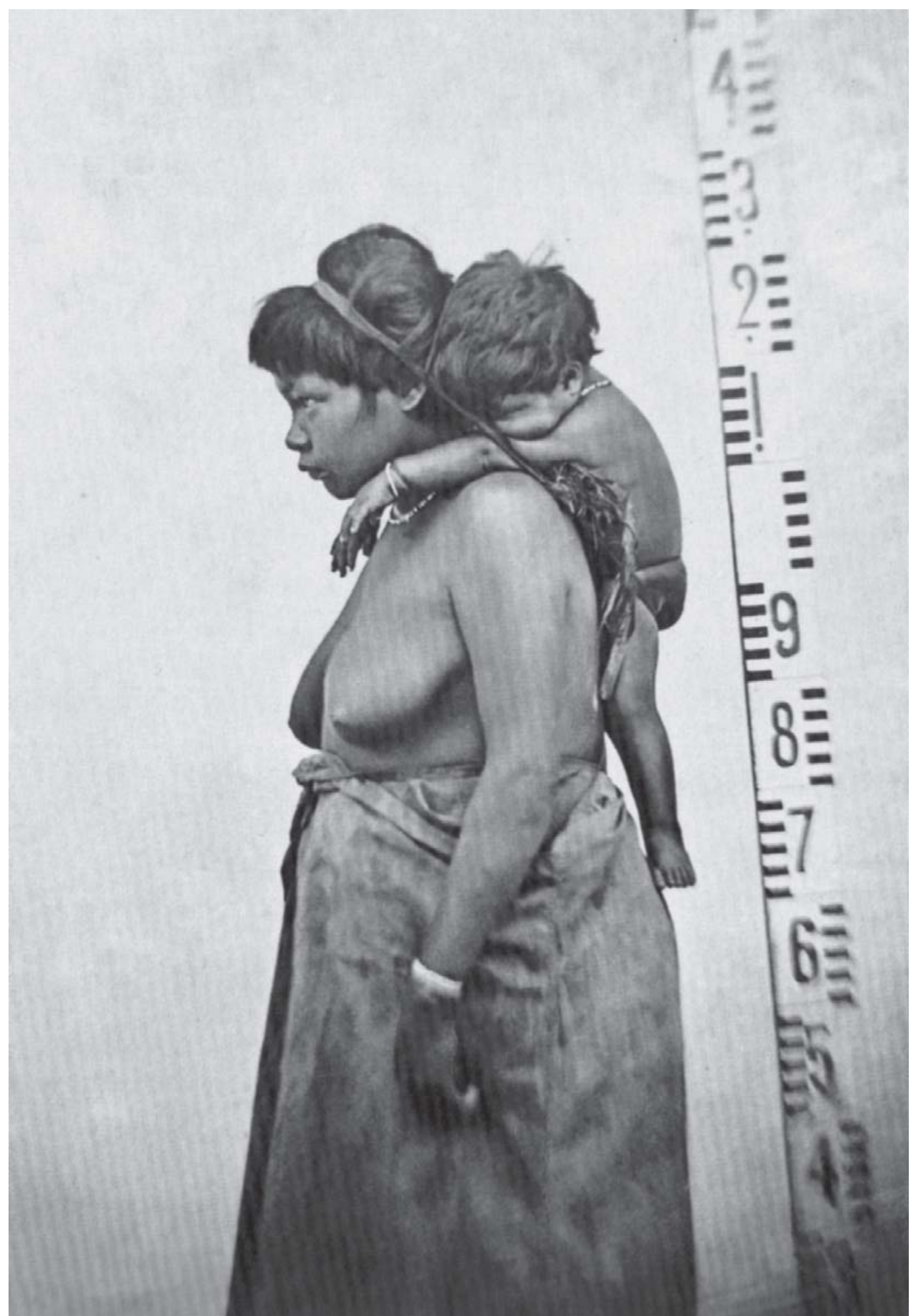

Figura 4: Botocudos do sul da Bahia, 1875, foto de Marc Ferrez (Coleção Gilberto Ferrez, Acervo Instituto Moreira Salles) 


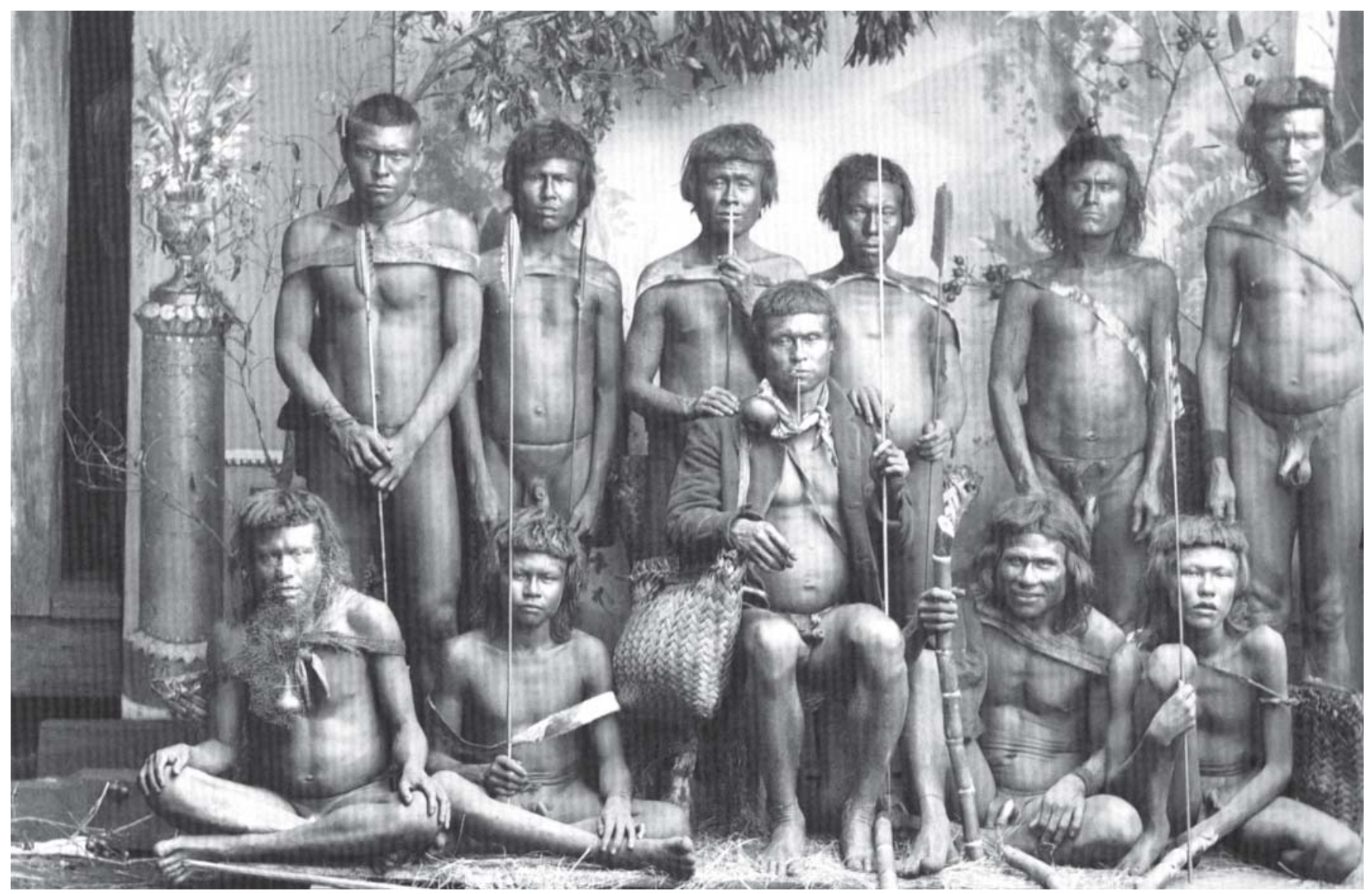

Figura 5: Índios bororo, 1880, foto de Marc Ferrez (Coleção Gilberto Ferrez, Acervo Instituto Moreira Salles)

Em uma imagem épica para o período, Ferrez levou um grupo de índios bororo para um estúdio, em passagem por Mato Grosso, e produziu uma imagem domesticada do selvagem, circunstanciado pela encenação fotográfica do estúdio. O selvagem aparece cerceado pelo ato fotográfico e alça um sabor inequívoco no imaginário: a existência desses povos tradicionais, mesmo dominados pelo aparelho e pelo olhar do fotógrafo. A natureza, o habitat deixam de ser importantes; são representações, um pano de fundo para a imagem. Seus olhares diretos e nobres ignoram as agonias do contato. Entretanto, na cronologia de Marc Ferrez publicada nos Cadernos de Fotografia Brasileira, do Instituto Moreira Salles, não aparece qualquer informação sobre sua passagem pelo Mato Grosso.

Os Botocudo no Espírito Santo também são encontrados em pequenos álbuns da Coleção da Biblioteca Nacional, em fotos realizadas por Walter Garbe. O autor aparece como participante no catálogo da Exposição Nacional de 1908 (Kossoy, 2002). O conjunto de imagens de Garbe se destaca pela proximidade de práticas e gestos culturais (fazendo fogo, catando piolhos em cabeças, tocando flautas ou uma simulação de caça, além de retratos muito descontraídos), sem olhares medrosos perante a câmera e sim de curiosidade sobre o evento fotográfico. Apesar de ser um conjunto pequeno, as imagens de Garbe se distinguem pelo grau de interação possível na articulação e produção dessas imagens. 


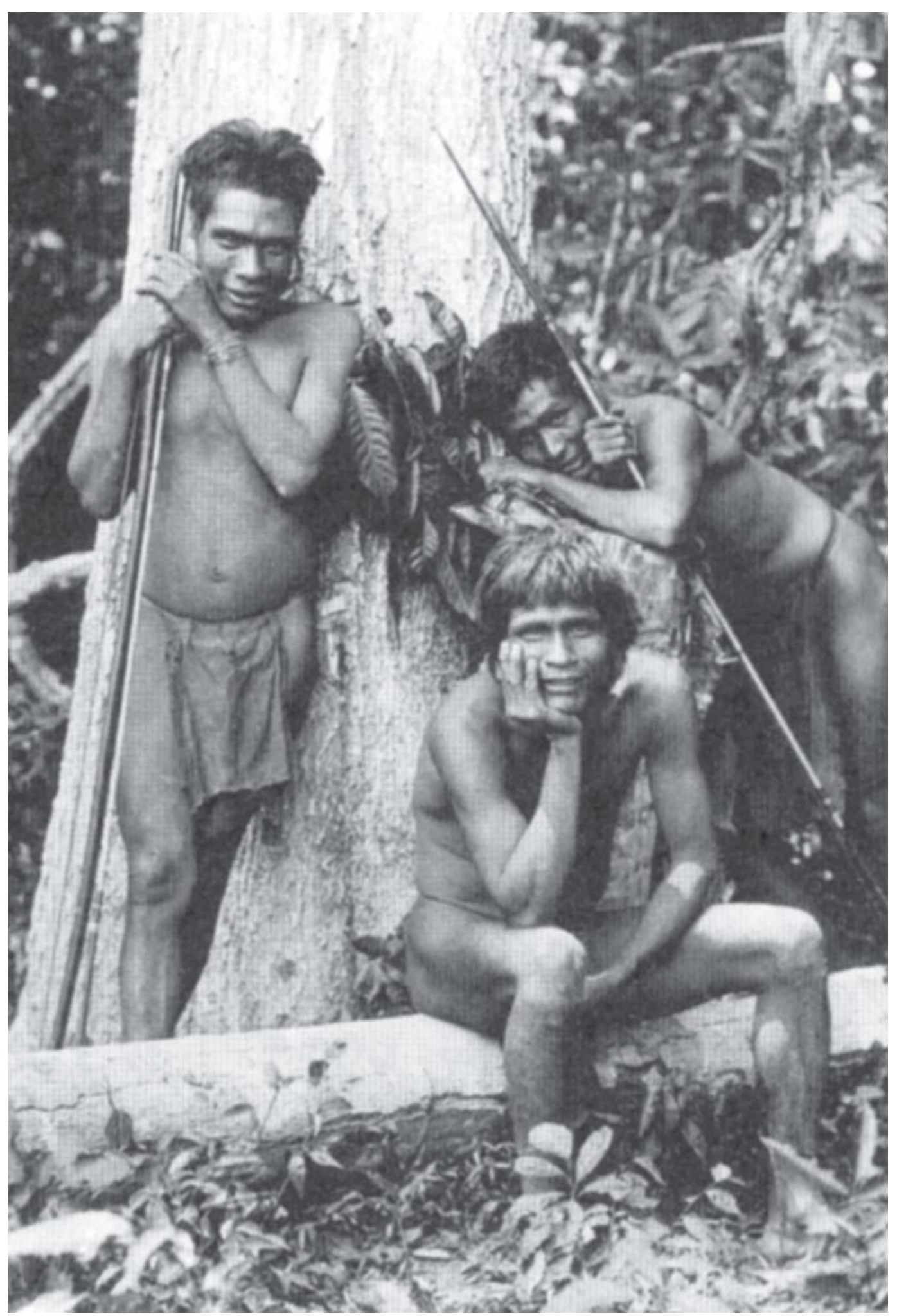

Figura 6: Índios botocudo, 1905, foto de Walter Gable (Biblioteca Nacional) 
Os leigos que observarem esses conjuntos fotográficos podem ser iludidos com a falsa noção de que os nossos primeiros habitantes eram todos de uma etnia chamada Botocudo, uma vez que somente os mesmos aparecerem nas imagens. Os portugueses nomeavam vários grupos que usavam botoques labiais e auriculares dessa forma, e assim incluíram etnias diversas, grupos linguísticos diversos como Botocudo, entre eles Kaigang, Xocleng, Krenak e Xetá. Eram chamados também de Aimoré, conhecidos nos textos pela resistência e pela prática da antropofagia. Os Botocudo são objeto de "Social organization na beliefs of Botocudos of Eastern Brazil", de Curt Nimuendajú (publicado em 1946 no periódico Southwestern Journal of Anthropology), e também aparecem no "Quadro das pesquisas de campo realizadas por Curt Nimuendajú", quando ele esteve nos estados da Bahia, Minas Gerais e Espírito Santo, entre 1938-1939, e no quadro "Frequência das tribos em grupos linguísticos" (Nimuendajú, 1981). Assim, notamos que a nomenclatura teve existência duradoura até a primeira metade do século XX.

Ao final do século temos alguns fotógrafos que se colocam em lugares distintos de seus colegas anteriores, se inserindo efetivamente em documentações pessoais, e a imagem do índio brasileiro passa a ter lugar em discursos científicos. Entre eles, o alemão Paul Ehrenreich, pouco conhecido entre nós, cuja obra foi localizada no Instituto Länderkunde, de Leipzig, Alemanha (Vasquez, 2000). Paul Ehrenreich estudou medicina, depois antropologia e etnologia e viajou para o Brasil entre 1884 e 1885. Participou de uma expedição ao Xingu entre 1887 e 1889 e, segundo Vasquez, depois lecionou antropologia na Universidade de Berlim, foi editor de revista científica e publicou livros sobre etnologia. De Ehrenreich somente um pequeno conjunto de 23 fotografias foi encontrado por Vasquez, na sua pesquisa sobre fotógrafos alemães no Brasil no século XIX.

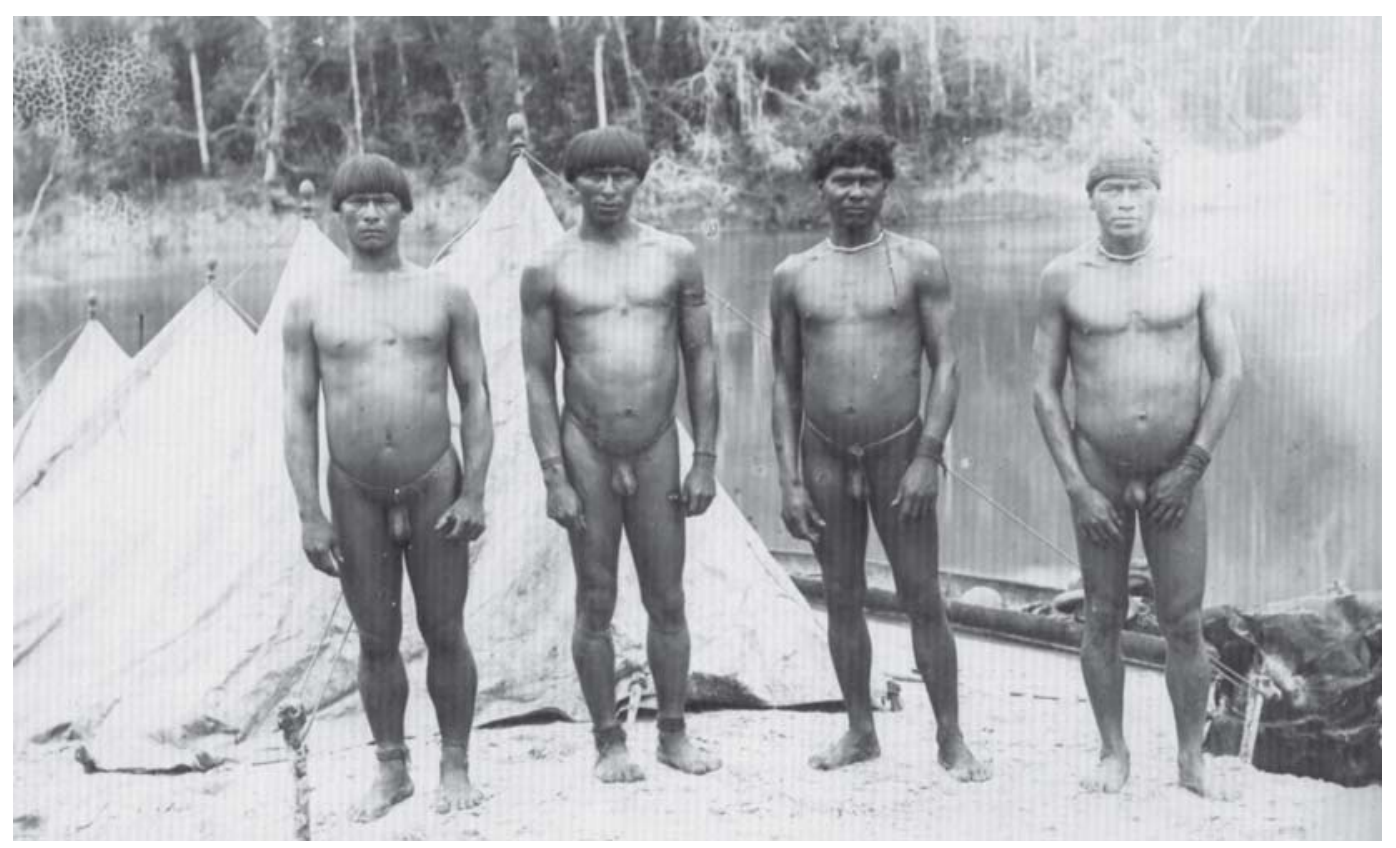

Figura 7: Grupo de índios meinaco, do Pará, 1894, foto de Paul Ehrenreich, coleção do Institut für Länderkunde (Vasquez, 2000) 


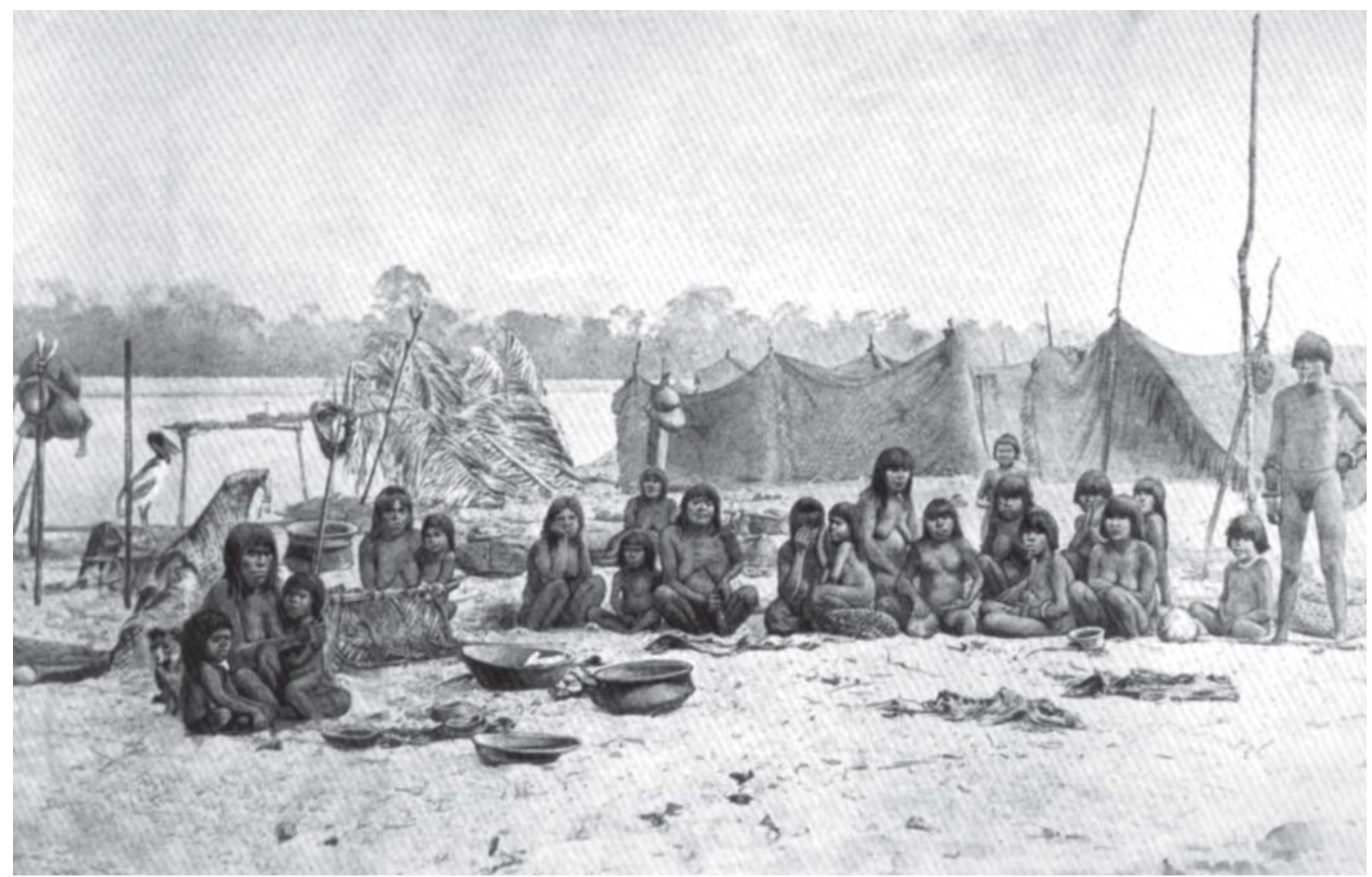

Figura 8: Família de índios, do Pará, 1894, foto de Paul Ehrenreich, coleção do Institut für Länderkunde (Vasquez, 2000)

Nesse novo quadro, Ermanno Estrandelli e George Huebner são exemplos de fotógrafos estrangeiros que se lançam na aventura amazônica, não esquecendo que Manaus se tornou importante pólo econômico com o ciclo da borracha, o que atraiu muitos estrangeiros ao país. Os dois fotógrafos se estabeleceram comercialmente em Belém e Manaus e se envolveram em expedições científicas. $\mathrm{O}$ italiano Ermanno Stradelli teve várias passagens pela Amazônia a partir de 1879 e se estabeleceu em Belém no final do século, naturalizando-se brasileiro e atuando também em advocacia. Com formação em etnologia, topografia, farmacologia e homeopatia, botânica, zoologia e fotografia, veio ao Brasil pela primeira vez em 1879 . Como outros exploradores, Stradelli tentou localizar as nascentes dos rios, principalmente a do rio Orenoco, que documentou em viagem posterior e sobre a qual escreveu um relatório em 1887 ("La spedizione Stradelli alle sorgenti dell Orinoco"). Sua presença fotográfica foi oficializada na expedição que remeteu imagens dos povos ribeirinhos próximos à cidade de Manaus e nos afluentes do rio Negro, para a Real Sociedade Geográfica Italiana, de Roma. Suas fotos estão no Arquivo Fotográfico da Sociedade Geográfica Italiana de Roma, entre elas 83 imagens realizadas durante as expedições no Brasil entre 1887 e 1889, com temas variados sobre rios, paisagens, a cidade de Manaus, índios e malocas da Amazônia e inscrições de pinturas rupestres do Alto Rio Negro. 


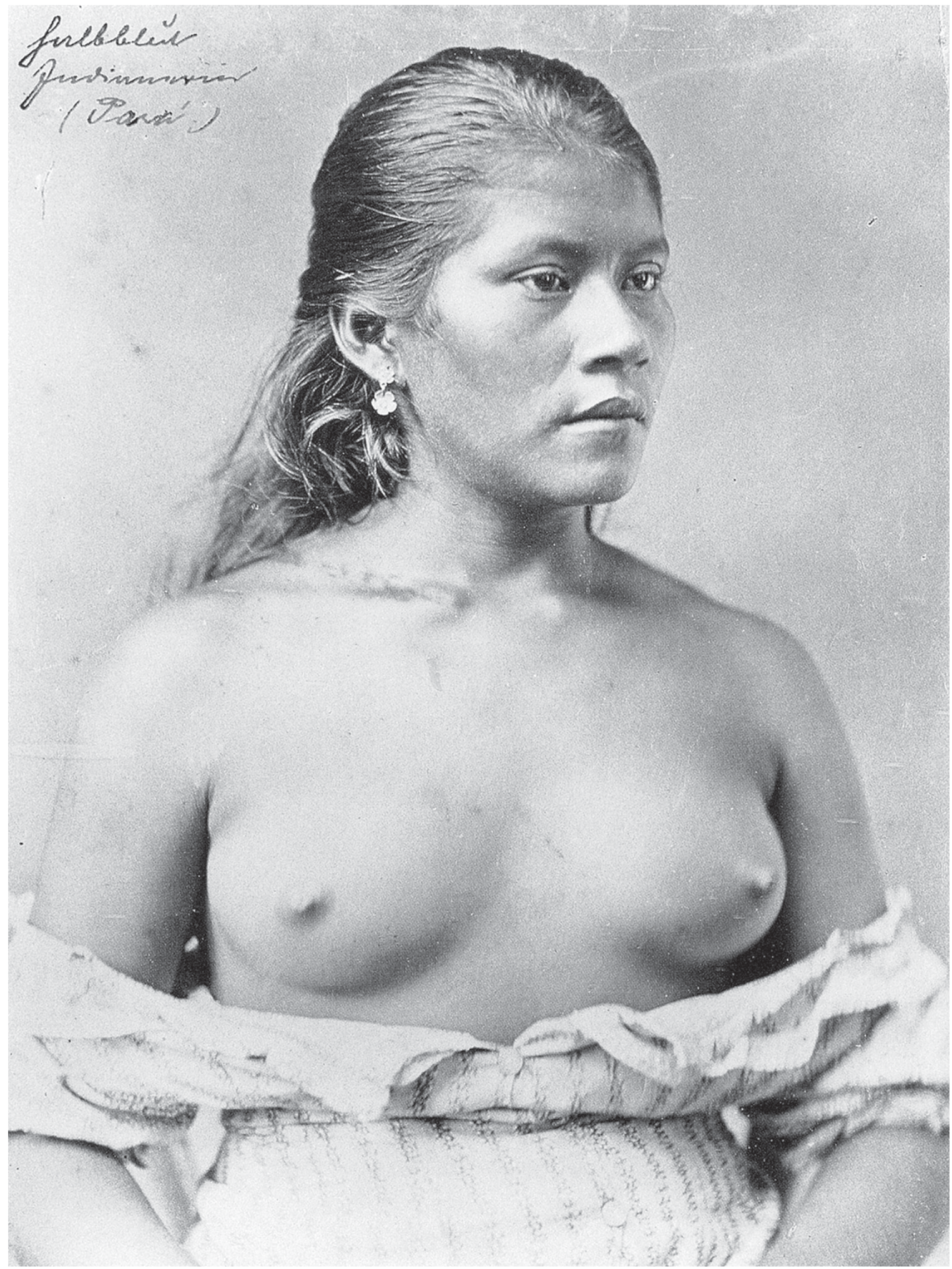

Figura 9: Índia paraense, 1900, foto de George Huebner, coleção Theodor Koch-Grünberg (Valentin, 2009) 

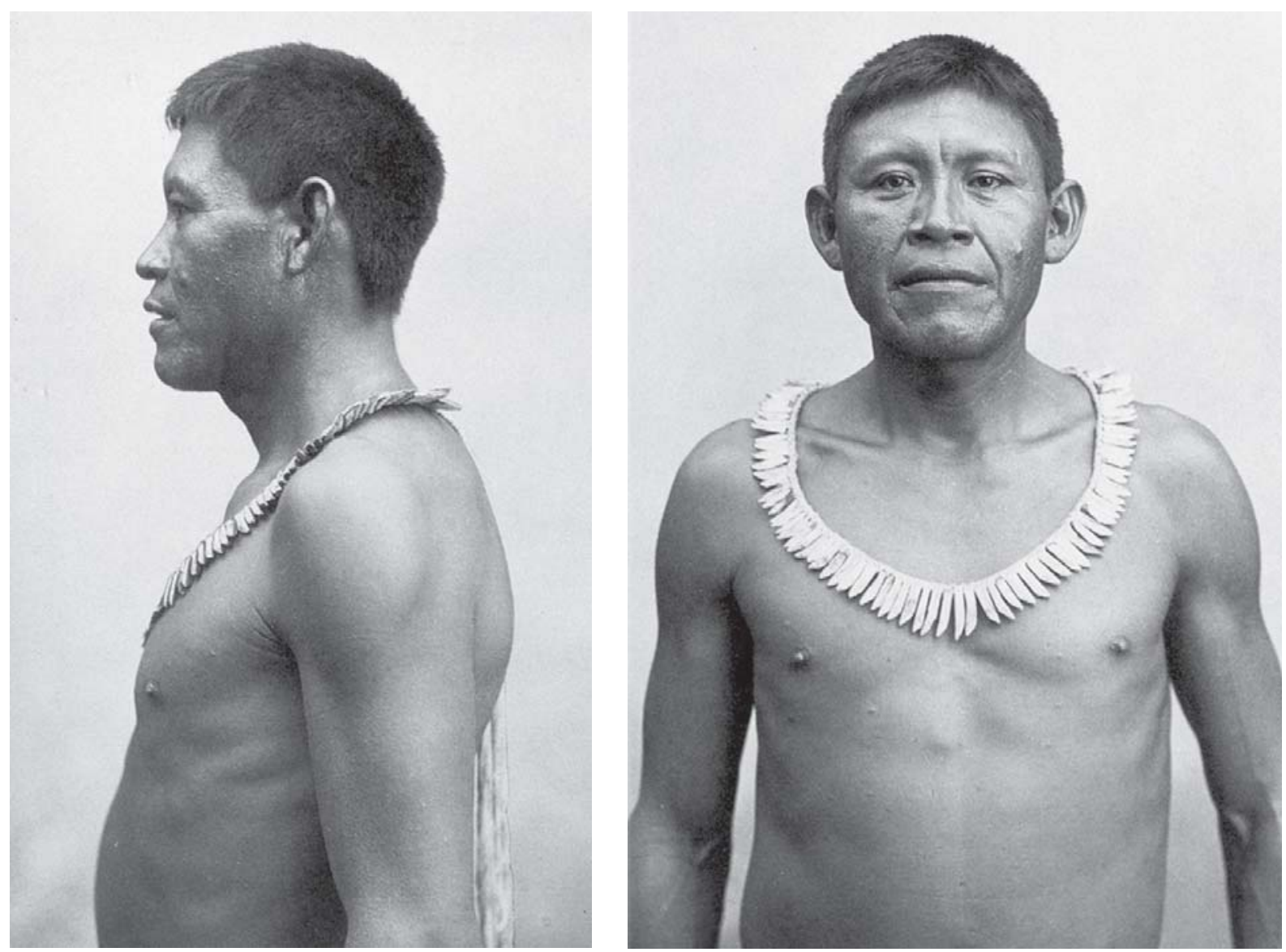

Figura 10: Índio macuxi, 1900, foto de George Huebner, coleção Theodor Koch-Grünberg (Valentin, 2009)

George Huebner, ao se estabelecer em Manaus com seu estúdio Fotografia Alemã, no final do século XIX, anunciou-se como membro da Sociedade Geográfica de Dresden. Documentou a cidade de Manaus e sua gente, e tem vasta produção sobre índios amazônicos em habitat próprio ou em cenas tiradas em seu atelier, que se tornou o mais importante da cidade. ${ }^{1}$ Segundo Valentin (2009), a grande produção de Huebner em álbuns comparativos, cartões-postais (colorizados) e publicações em revistas científicas forjou uma primeira e referente visão sobre a Amazônia e seus povos das florestas no imaginário europeu. Antes de se estabelecer em Manaus, o fotógrafo fez viagens para o Peru, onde conheceu em 1888 o fotógrafo alemão Charles Kroehle. Durante três anos os dois percorreram milhares de quilômetros do território peruano, cobrindo desde os altiplanos andinos até a costa do Pacífico e a região amazônica. Huebner retornou a Dresden em 1892, publicou textos ilustrados em revistas de ciência popular e viagens e ministrou palestras em sociedades científicas, além de fornecer imagens para artigos científicos. Em 1894 voltou à Amazônia e fez duas expedições: a primeira, à nascente do Orinoco, já na Venezuela, e a outra por um longo trecho do rio Branco, afluente do rio Negro. Nos oito meses em que permaneceu na floresta amazônica, Huebner também aprofundou seus conhecimentos de botânica amazônica, ao coletar e documentar espécimes da flora, especialmente de orquídeas. 
Huebner fez inúmeras expedições fotográficas ao interior amazônico e manteve contato e trabalhou para muitos cientistas e pesquisadores, principalmente o etnólogo Theodor Koch-Grünberg, cujos artigos científicos publicados em revistas especializadas contaram com imagens cedidas por ele. Para Valentin (2009), esse aprendizado lhe garantiu importantes contatos no meio científico europeu e garantiu sua sobrevivência em Manaus, após o declínio da borracha. Em 1901 associou-se a Libânio do Amaral, professor de Belas Artes, e em 1906 eles adquiriram, em Belém, o ateliê fotográfico Fidanza, ampliando ainda mais seu mercado de trabalho. Quatro anos mais tarde, abriram uma filial no Rio de Janeiro, na avenida Central. Em sua detalhada investigação, Valentin assim se refere à presença de Huebner na capital federal:

No escopo da pesquisa aqui apresentada, as parcerias estabelecidas por Huebner nesse período abriram novas possibilidades e estratégias de produção, exibição e circulação de sua fotografia de indígenas. Suas fotografias de "Indianer" mereceram destaque nas ilustrações do álbum "O Valle do Rio Branco", ressaltadas por desenhos de objetos etnográficos e paisagens amazônicas. Essa edição, bem cuidada, patrocinada pelo Estado do Amazonas e produzida em Dresden, foi elogiada e premiada em 1908 na Exposição Nacional do Rio de Janeiro, para onde Huebner viajou e pôde receber o 'reconhecimento' ao qual sempre se referia, desde os primeiros escritos. Ali, vislumbrou, também, a possibilidade de abrir uma filial, expandindo seus negócios para a capital federal. Os 'Indianer' se destacaram, ainda, na série de cartões-postais, produzidos em grandes tiragens e alcançando um público internacional. Finalmente, foram levados para dentro do espaço cênico do atelier para ali serem reconfigurados como objeto de estudo (p.281).

Do ponto de vista de uma ciência que se apropriava de um aparelho programático dentro de um modelo positivista de representação da realidade, o elemento exótico muitas vezes se sobrepunha ao etnográfico e configurava-se, portanto, uma superposição do fascínio pelas imagens dos nativos em relação ao elemento documental. Ao analisar algumas fotografias do período, Susana Dobal (2001, p.78) ressalta:

Se a ciência cedeu ao apelo do exótico, ela também assimilou a sua mesma ambiguidade: de um lado, havia a necessidade de afirmar a diferença e constituir um discurso baseado na ideia de superioridade racial para melhor submeter; de outro lado, e também corroborado pela prática fotográfica, havia a fascinação por uma outra civilização que era vista e representada como passivamente à disposição dos recém-chegados.

A produção isolada dos fotógrafos aqui elencados, pertencentes ao século XIX e nas fronteiras do século XX, demonstram inicialmente uma presença exótica dos nativos nos trópicos - similar a muitas outras produções -, a alimentar o gabinete de curiosidades do mundo europeu sobre povos distantes e 'primitivos'. Algumas fotos do período são abusivas de práticas de domínio do corpo de nativos como espetáculo visual e com grau elevado de superioridade na condução da produção fotográfica. As fotos realizadas pelo reverendo George Brown nas Ilhas Salomon, em 1902, são exemplares desse abuso: em uma série de fotos, algumas do mesmo enquadramento e da mesma pessoa, o furo no lóbulo de um nativo é preenchido por um grande relógio, anunciando-se a futura aculturação de forma exorbitante (Webb, 1995, p.195-198). 
Enjaulados em exposições presenciais, foram domesticados pela fotografia de estúdio, na qual o fotógrafo foi o articulador cênico de uma representação deslocada da cultura nativa. Sem dúvida, a coleção que nos chamou mais atenção foi realizada por Garbe, na tentativa de documentar ações realísticas. E não obstante as simulações - que hoje podemos determinar -, houve um pacto de encenação muito distinto das fotografias posadas de estúdio e mais difíceis nas condições técnicas de campo da fotografia de então.

As fotografias do período transitam entre o exótico distante e uma primeira tentativa de presença etnográfica como informação, mas muito mais pobre daquela que seria desenvolvida na emergente escola cultural norte-americana da passagem do século, que teve Franz Boas como defensor de práticas fotográficas na pesquisa de campo antropológica e incentivador do trabalho de Margaret Mead e Gregory Bateson; ou ainda a narrativa fotográfica no trabalho de campo de Bronislaw Malinowsky (Samain, 1995).

\section{O nacional e o fotográfico: a ocupação simbólica do território}

No começo do século XX anunciam-se mudanças no trato fotográfico com as populações indígenas, principalmente as da ampla produção fotográfica da Comissão Rondon. De outra parte, as práticas evoluem também para rumos muito diferentes. As impressionantes imagens levantadas na pesquisa de Silvio Coelho dos Santos (1997) demonstram o genocídio e um começo imagético desastroso dos índios Xocleng, em Santa Catarina. Imagens recuperadas em arquivos pessoais e museus, mas de pouca circulação à época em que foram realizadas, mostram somente grupos de mulheres e crianças como uma espécie de troféu de guerra dos chamados bugreiros, que investiam como ponta de lança de um capitalismo selvagem à procura de boas terras no oeste catarinense.

Na Argentina, a ocupação territorial aconteceu de forma semelhante, mas incorporada a uma política oficial. Deu-se o nome La Campaña del Desierto à ocupação dos ricos e férteis campos dos pampas argentinos pelo general Julio Argentino Rocas, à frente de tropas federais, quando nativos da área foram expulsos e as terras, distribuídas entre membros da aristocracia rural. Podemos alinhar também as fotografias produzidas pelos missionários salesianos entre os índios bororo, mas o que temos nesse caso são a ausência do tradicional e a presença de uma pacificação religiosa, indicada em imagens de índios em processo de civilização. As fotos foram utilizadas como suporte para essa prática, convencimento daquela catequização e elevação do indígena para outro lugar no campo do nacional (Novaes, 1993).

Cândido Mariano da Silva Rondon, ainda tenente e oficial engenheiro, começou como ajudante nas primeiras comissões de linhas telegráficas formadas no último ano do Império, em 1889. Em 1891, já como capitão, assumiu a chefia da Comissão Construtora de Linhas Telegráficas do Araguaia e também a Comissão Construtora de Linhas Telegráficas no Estado de Mato Grosso, de Cuiabá a Corumbá, prolongadas até as fronteiras de Paraguai e Bolívia, entre 1900 e 1906. Assim como Rondon, seu principal assessor para a produção fotográfica e cinematográfica, Luis Thomaz Reis, também era oficial engenheiro, e ambos foram formados na Escola Militar da Praia Vermelha, no Rio de Janeiro.

As ações de reconhecimento e mapeamento das terras e rios brasileiros efetuadas pela Comissão estenderam-se por mais de 50 mil quilômetros. Colocaram Rondon frente a 


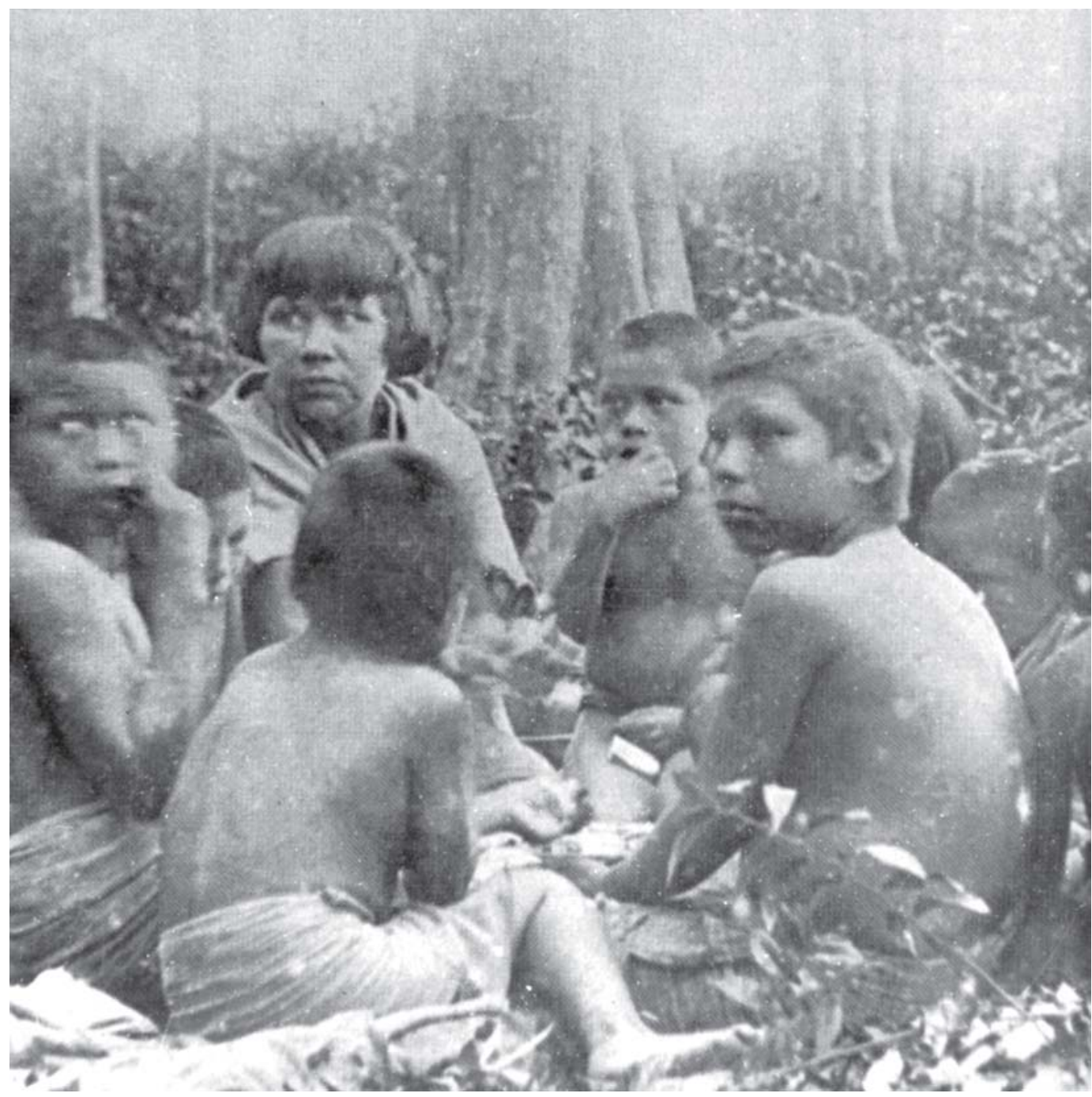

Figura 11: Índios xocleng, Blumenau, 1905, fotógrafo desconhecido, coleção de Silvio Coelho dos Santos (Santos, 1997)

frente, no sertão, com vários grupos indígenas que tinham pouco contato com a 'civilização', levando-o a criar, em 1910, o Serviço de Proteção ao Índio e Localização do Trabalhos Nacional (SPILTN), depois alterado para Serviço de Proteção ao Índio (SPI), como ficou mais conhecido. Em uma de suas principais ações, Rondon chefiou a Comissão de Linhas Telegráficas Estratégicas de Mato Grosso ao Amazonas, encerrada somente em 1916. O SPI esteve ligado ao Ministério da Agricultura e trazia a ideia de integração das populações indígenas ao processo produtivo nacional. Influenciado fortemente pelo positivismo, Rondon deu uma característica fortemente humanística às atividades do Serviço, que em 1964 foi transformado em Fundação Nacional do Índio, em operação até os dias atuais.

A Comissão Rondon tinha o espírito científico das grandes expedições e sempre se fazia acompanhar por botânicos, zoólogos e outros cientistas, que realizavam levantamentos 
da fauna e da flora. O levantamento topográfico e geográfico era coordenado pelo próprio Rondon e seus ajudantes, e foram feitas descrições de cultura material e idiomas de alguns grupos indígenas, além de medições antropométricas. Todos esses trabalhos vieram a público com "Publicações da Comissão Rondon", em pequenos e grandes volumes. Entre as atividades, destacou-se a produção de filmes e de fotografias, principalmente a partir de 1912, quando foi criada a Seção de Cinematografia e Fotografia, sob a responsabilidade do então tenente Luiz Thomaz Reis, o principal cineasta e fotógrafo da Comissão Rondon (Tacca, 2005). Entretanto, ele não seria o único fotógrafo das diversas expedições, e podemos destacar outros como José Loro, Charlotte Rosenbaum e Carlos Lako.

Entre as publicações da Comissão Rondon, as últimas foram dedicadas às imagens fotográficas e fotogramas cinematográficos publicados em três volumes com o título de "Índios do Brasil", entre 1946 e 1953 (Rondon, 1946, 1953, 1956). Depois do fim das comissões de expansão do telégrafo, principalmente pelo surgimento do telégrafo sem fio, Rondon esteve à frente da Inspetoria de Fronteiras, entre 1934 e 1938, e uma grande parte da documentação fotográfica dos grupos indígenas da Amazônia foi feita nesse período. Rondon considerava a Inspetoria de Fronteiras a "filha mais dileta da Comissão Rondon". Mantendo-se a equipe de trabalho, todo esse período de produção de imagens pode ser considerado uma extensão das atividades da comissão.

Rondon preparava vários álbuns fotográficos das atividades da Comissão e os enviava para as autoridades mais importantes do governo brasileiro. Os álbuns, os artigos publicados nos principais jornais do país e principalmente as apresentações dos filmes seguidas de conferências, funcionavam como uma espécie de marketing pessoal e uma forma de persuasão para a continuidade das atividades da comissão. Visavam principalmente a elite urbana, sedenta de imagens e informações sobre o sertão brasileiro, e principal grupo formador de opinião. Assim, Rondon alimentava o espírito nacionalista construindo etnografias de um ponto de vista estratégico e simbólico: a ocupação do oeste brasileiro através da comunicação pelo telégrafo, pela visualidade da fotografia e do cinema mudo.

Podemos categorizar a produção imagética da Comissão Rondon em três instâncias (Tacca, 1999). A primeira deve-se principalmente ao filme Os índios coroado, captado em 1916 e editado em 1917, e considerado um dos primeiros filmes do cinema etnográfico no mundo, que ficou conhecido pelo seu segundo título: Rituais e festas bororo. A película mostra o ritual funerário entre os índios bororo, da aldeia de São Lourenço, no Mato Grosso. Nesse filme, o índio é mostrado como um 'mito de origem' da nação brasileira, que ali se encontravam, com seus costumes tradicionais, desde os tempos ancestrais. Aqueles que veem o filme de Reis pela primeira vez podem ter a impressão de que os indígenas estavam completamente isolados ou quase sem contato com os brancos, em virtude da ênfase nos processos ritualísticos, nas práticas culturais como o artesanato e na busca da alimentação pela pesca. Reis não explicita, em nenhuma passagem visual e tampouco nas legendas, a presença dos missionários salesianos na região desde o final do século XIX, quando introduziram técnicas não tradicionais entre os Bororo (Novaes, 1993). O cultivo e a moagem da cana-de-açúcar foi uma delas, e surpreendentemente, embora cenas dessas práticas tenham sido filmadas, elas não fazem parte da edição final do filme, transparecendo que Reis pretendia mostrar a ideia de um índio "como nos tempos do Descobrimento", 
conforme a cartela que encerra a película. Na publicação de Índios do Brasil, fotogramas cinema-tográficos mesclam-se a fotografias e criam uma nova ordem narrativa, e o fato de cenas de aculturação não terem sido aproveitadas na montagem dá ao filme uma impressão bruta da existência ainda tradicional desse grupo étnico, como uma espécie de mito de origem da nação brasileira, um índio tradicional, ainda 'selvagem'.

O cruzamento entre filmes e fotografias foi uma prática inovadora na produção da Comissão Rondon e a segunda categorização se dá no campo da pacificação, quando imagens demonstram um índio dócil e sujeito a mudanças pelo avanço civilizatório. Constrói-se assim uma imagem de sujeição e não de impedimento à ocupação territorial da nação. No filme Ronuro: selvas do Xingu (1932), captado em 1924, assim como na hibridização da narrativa impressa com fotografias, a natureza imagética aparece como a exploração do território e a criação de um índio genérico, vestido ao final com roupas 'civilizadas'; uma existência por semelhança, afinal não estavam nus.
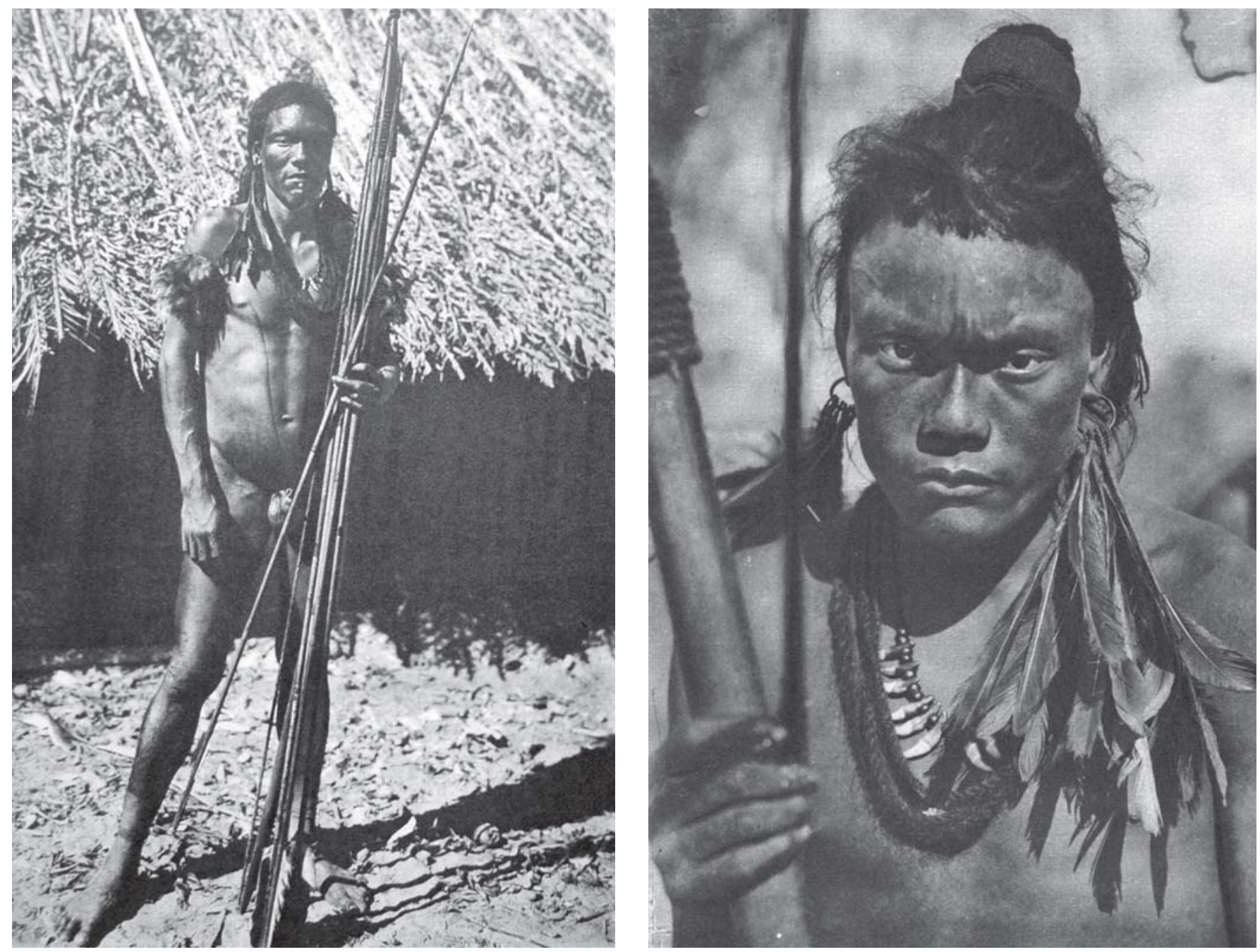

Figuras 12 e 13: Índio umutina, c.1910, fotos de José Loro (Museu do Índio) 

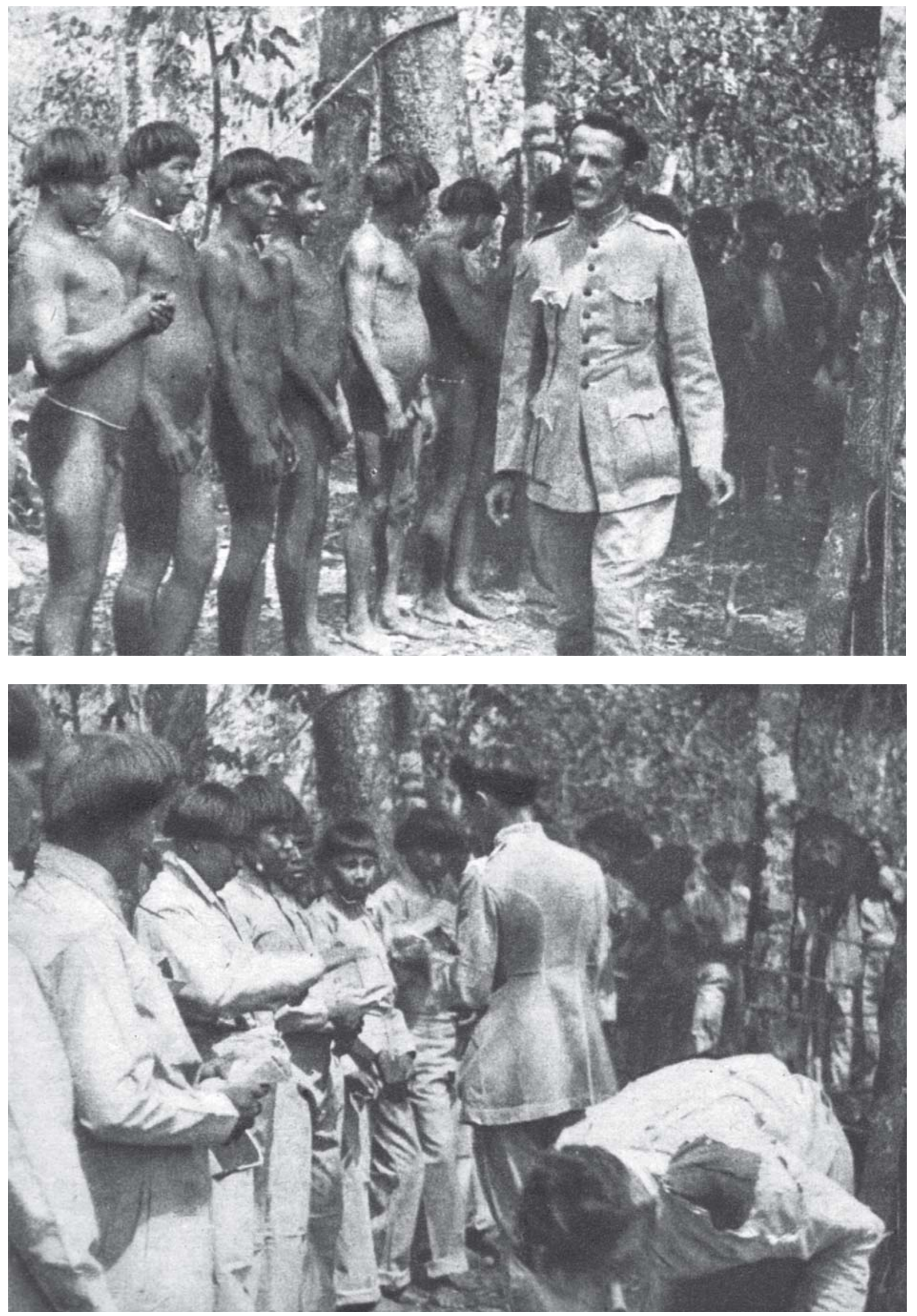

Figuras 14 e 15: Fotogramas do filme Ronuro: selvas do Xingu, de 1932 (Museu do Índio) 
A terceira categorização da imagem do índio brasileiro pela Comissão Rondon é a construção imagética da existência de grupos tradicionais que aceitam a nacionalidade da bandeira e de outros símbolos da nação reconhecendo, em alguns casos, a fronteira nacional. Da mesma forma, os fotogramas e as fotografias se mesclam na exploração das últimas fronteiras, e os filmes Inspetorias de Fronteira (1938) e Viagem ao Roraimã (1932), junto às fotografias, são exemplares da condução para uma integração do índio pela ação civilizatória do Estado, na qual a imagem simbólica do índio fronteiriço ao lado da bandeira nacional marca a existência de um índio brasileiro, e não somente índio.

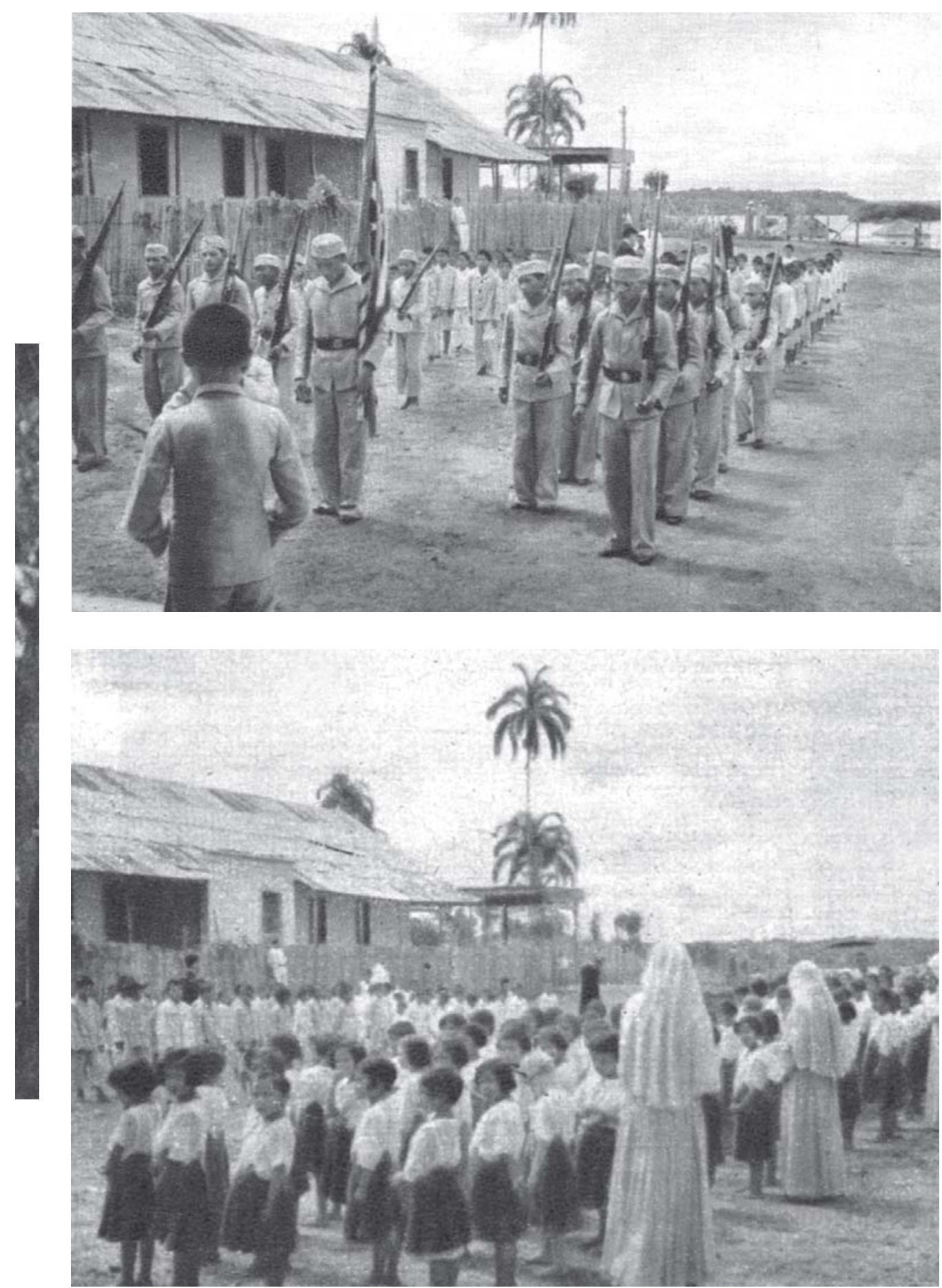

Figuras 16 e 17: Missões

Salesianas, Rio Negro, 1938, foto de Charlote

Rosebaum

(Museu do Índio) 
Fernando de Tacca

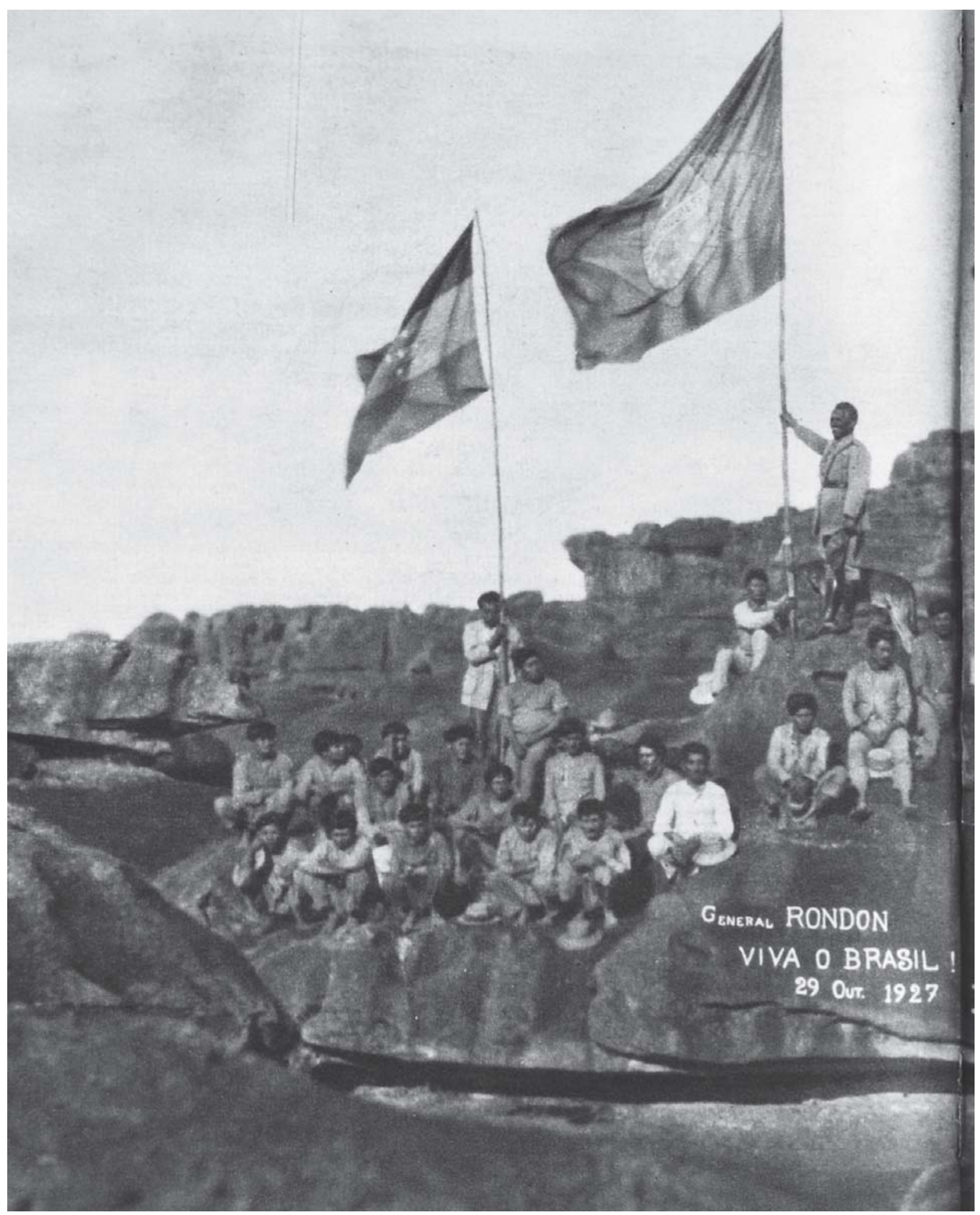

Figura 18: Rondon na fronteira do Brasil com Venezuela e Guiana Inglesa, com índios macuxi, em 27 de outubro de 1927, foto de Benjamin Rondon (Museu do Índio) 
O índio na fotografia brasileira

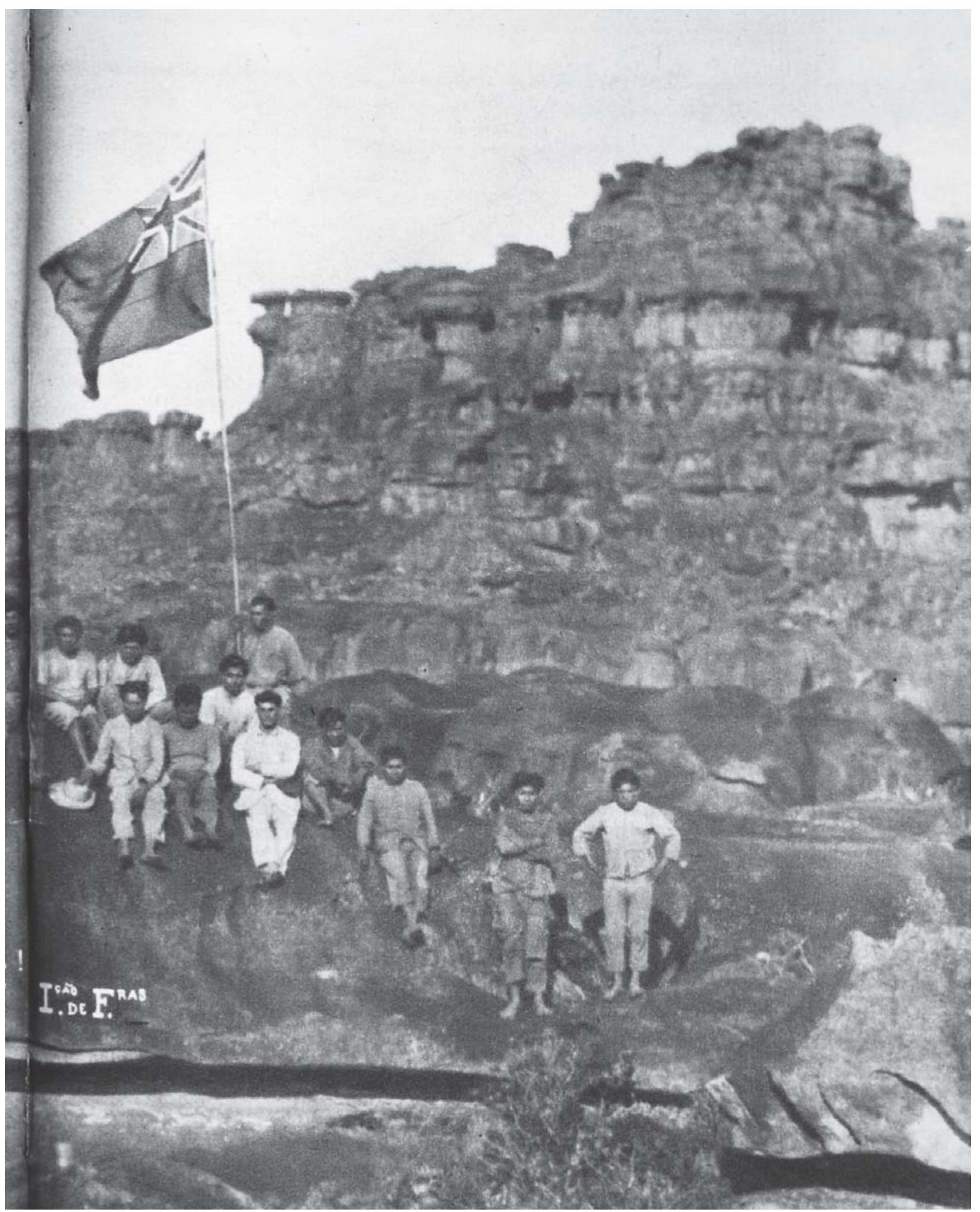


Como uma continuidade da Comissão Rondon e com uma metodologia detalhada de indexação das imagens, a Seção de Estudos do SPI, criada no começo da década de 1940, produziu impressionante acervo de aproximadamente dez mil negativos de grupos étnicos. Harald Schultz e Heinz Foerthmann foram seus principais fotógrafos, e a produção pode ser classificada como umas das primeiras frentes da fotografia moderna no Brasil, no campo da documentação. Festas, cerimônias, rituais e cultura material são os temas da documentação de caráter etnográfico. O que nos chama mais atenção é a organização do material, até hoje mantida conforme feita por seus fotógrafos. Identificamos uma necessidade de compreender visualmente esses povos pela ampla produção fotográficas das características diversas das culturas indígenas. Ainda pouco estudado, esse acervo de imagens desloca a questão indígena dos campos anteriores, do exótico ou da afirmação da territorialidade nacional, para um lugar de estudo e compreensão mais ampla da existência da diversidade étnica no Brasil.

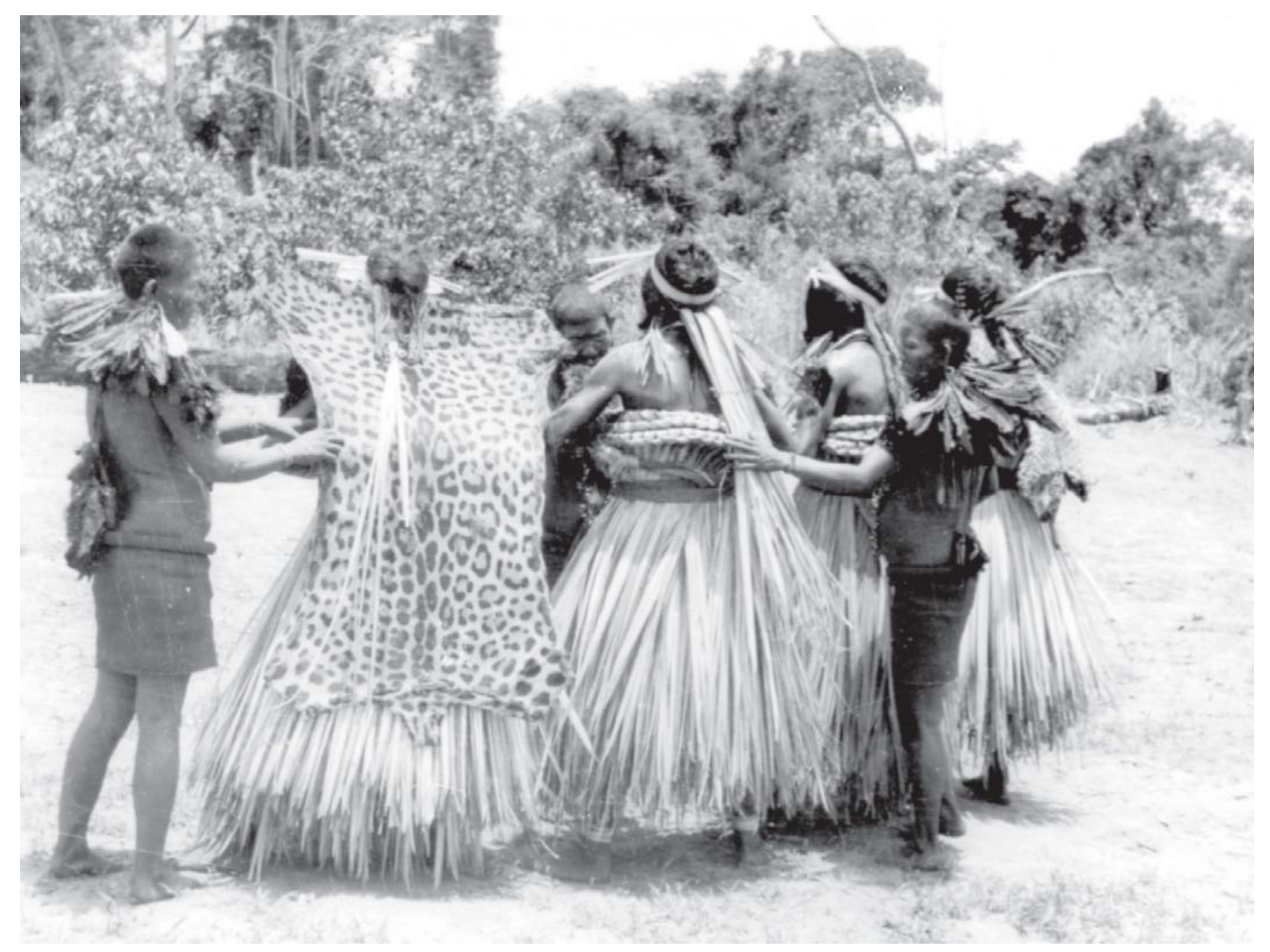

Figura 19: Funeral umutina, em Mato Grosso, 1943-1945, foto de Harald Schultz (Museu do Índio) 
Em uma das muitas expedições da Seção de Estudos do SPI, Heinz Foerthmann acompanhou Darcy Ribeiro, entre 1949 a 1951, às aldeias dos índios urubu-ka'apor. O resultado dessas incursões foi revelado recentemente com a publicação dos diários de campo de Darcy Ribeiro (1996), junto com as fotos realizadas por ele mesmo e por Foerthmann. Tal publicação concretiza o lugar da fotografia na etnografia sobre os índios brasileiros, como prática da Seção de Estudos do SPI. Ribeiro ressalta, no prefácio do livro, as dificuldades de reconhecer a autoria das inúmeras fotografias, pelo fato de elas terem sido feitas por ele e por Foerthmann, e assim foram arquivadas. Diz, ao final: "Aquelas em que apareço são dele, claro. As boas também". Entretanto, pesquisas realizadas no Museu do Índio para indexação de informações permitiram identificar as respectivas autorias.

A expedição teve início em 5 de novembro de 1949 e terminou em abril de 1950. Os encarregados da Seção de Estudos foram: Max Boudin, linguista francês, responsável pela documentação sonográfica; Heinz Foerthmann, pela documentação fotocinematográfica e Darcy Ribeiro, etnólogo, orientador dos trabalhos. As informações para identificação destas fotografias foram pesquisadas em relatório sobre a realização das pesquisas de que Darcy Ribeiro foi incumbido de 1949/1950 sobre condições de vida da população indígena do Rio Gurupi, apresentado por Darcy Ribeiro a 6ª Delegacia Regional em 22/05/1950 (Museu do Índio, s.d.).

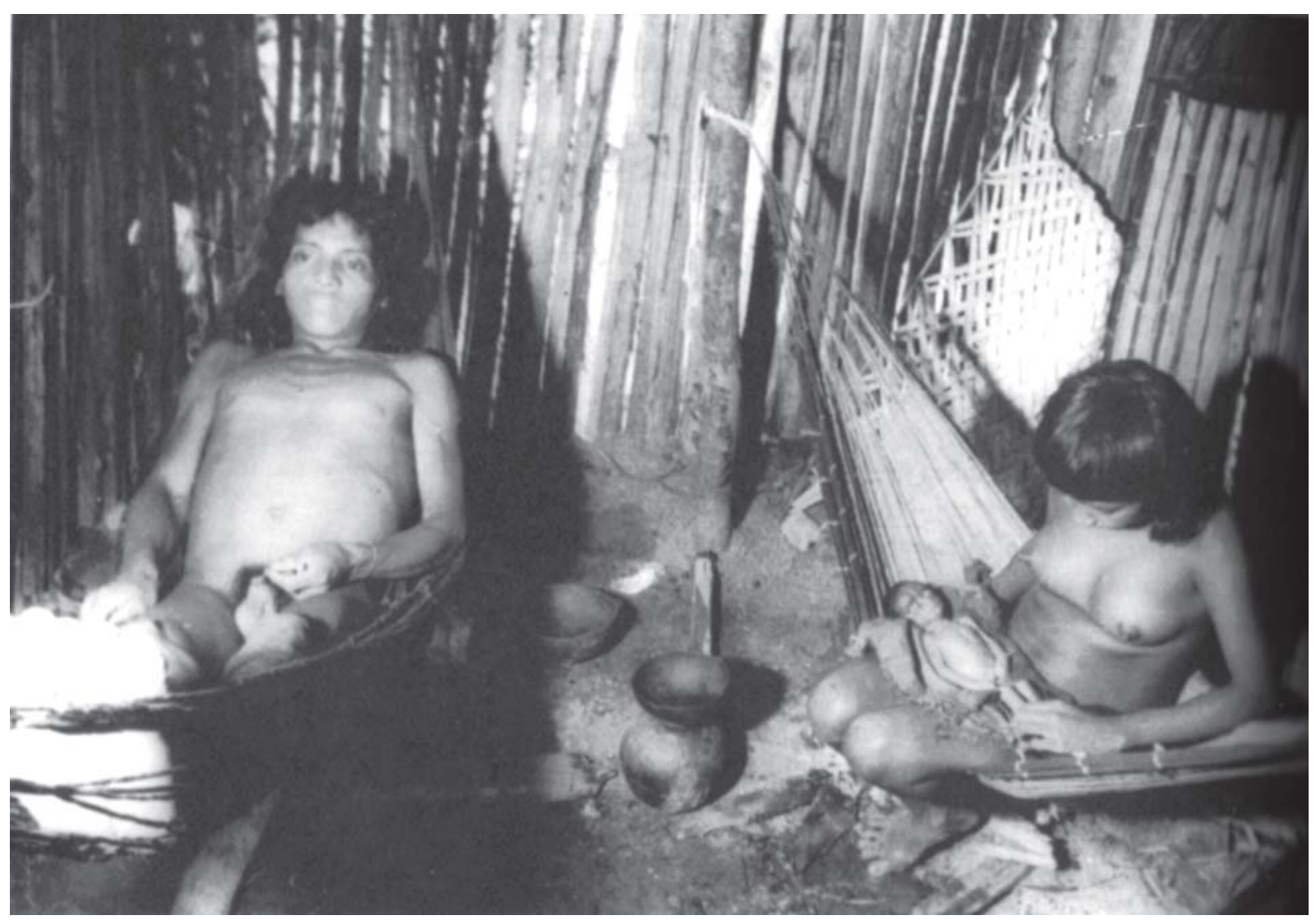

Figura 20: Ritual de nascimento realizado por casal urubu na casa indígena, Maranhão, 1949, foto de Heinz Foerthmann (Museu do Índio) 
Fernando de Tacca

Ainda no campo da introdução da fotografia moderna no Brasil, a revista $O$ Cruzeiro foi o principal veículo de comunicação. Nela o fotojornalismo assumiu novas faces, na mediação dos fatos sociais. Jean Manzon formou um grupo de fotógrafos que se tornaram referências e reconfiguraram a narratividade fotográfica no Brasil, também no começo dos anos 1940. Como exemplos, temos as reportagens publicadas como uma espécie de novela, sobre o casamento da índia kalapálo Diacuí com um sertanista. As reportagens ganharam os títulos "Minha noiva é uma índia" (1 nov. 1952), "Kalapalos invadem a 'cuiabá' dos arranha-céus" (29 nov. 1952) e "Abandonada pelo branco morreu Diacuí" (22 ago. 1953). A proposta de uma mestiçagem das populações brasileiras é clara, na narrativa dos episódios desse casamento frustrado, pois a índia morreu ao voltar para sua aldeia e a criança foi adotada por uma família branca. Se o casamento não deu certo, a criança seguiu seu rumo na 'civilidade' (Costa, 2004).

De outra parte, a revista acompanhou a conhecida Expedição Roncador-Xingu e a pacificação dos índios xavante, também com várias reportagens. Nesse caso atribui-se valor imagético à resistência daquele grupo, na conhecida fotografia em que aparecem atirando flechas em direção ao avião de onde são fotografados por Jean Manzon. Entretanto, no

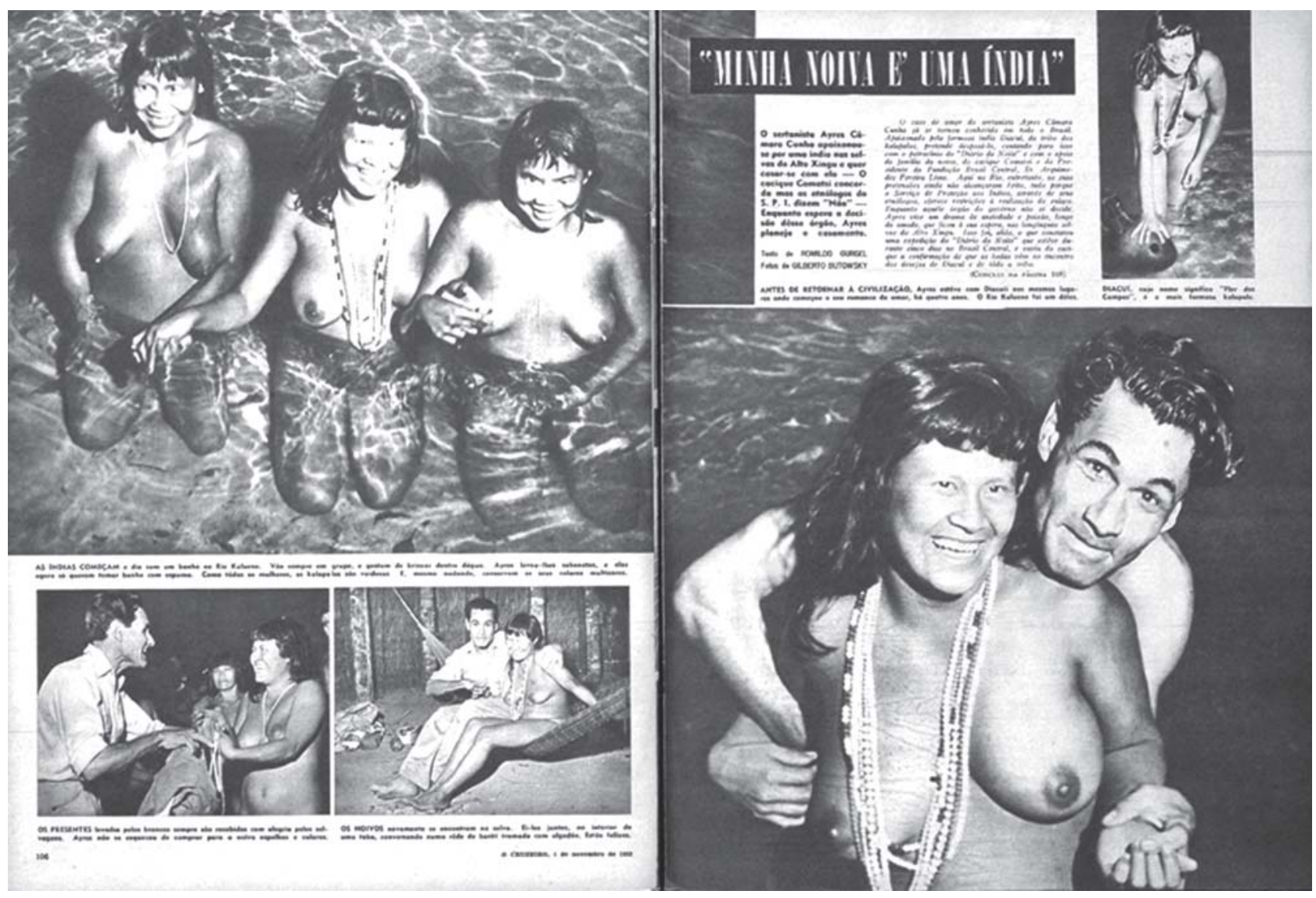

Figuras 21 e 22: Reportagens da revista O Cruzeiro, coleção Revista O Cruzeiro (Museu de Comunicação Social Hipólito da Costa) 
processo de contato acabaram por se render ao grande pássaro, como na foto de José Medeiros, em que um Xavante se abraça às rodas de uma aeronave.

A revista O Cruzeiro publicou, entre 1944 e 1949, uma série de reportagens sobre a Expedição Xingu-Roncador e proporcionou ao grande público uma participação mediática no processo de pacificação realizado pelo Estado, mas apontou a existência de populações ainda sem contato e vivendo de forma tradicional.

A imagem do índio tradicional contribui para a formação de um imaginário coletivo sobre o índio no Brasil, e devemos principalmente à Comissão Rondon e à revista O Cruzeiro a sedimentação dessa visão, ainda presente nos dias de hoje. Se retrocedermos um pouco mais de uma dezena de anos, podemos observar a ideia de 'selvagem'na polêmica reportagem da revista Veja sobre o caso Paulinho Paiacã, que denunciava um possível estupro de uma moça branca, cujo acusado foi depois julgado e inocentado. A capa da revista mostrava-o em pinturas tradicionais com o título "O selvagem" (em letras maiúsculas) e levantava dúvidas acerca de considerar Paulinho Paiacã um índio, pois ele dirigia, possuía carro e pilotava avião, além de ter certa estabilidade econômica. Para a revista Veja, ao índio caberia somente uma existência tradicional, sendo-lhe vedadas aculturações, mas o título
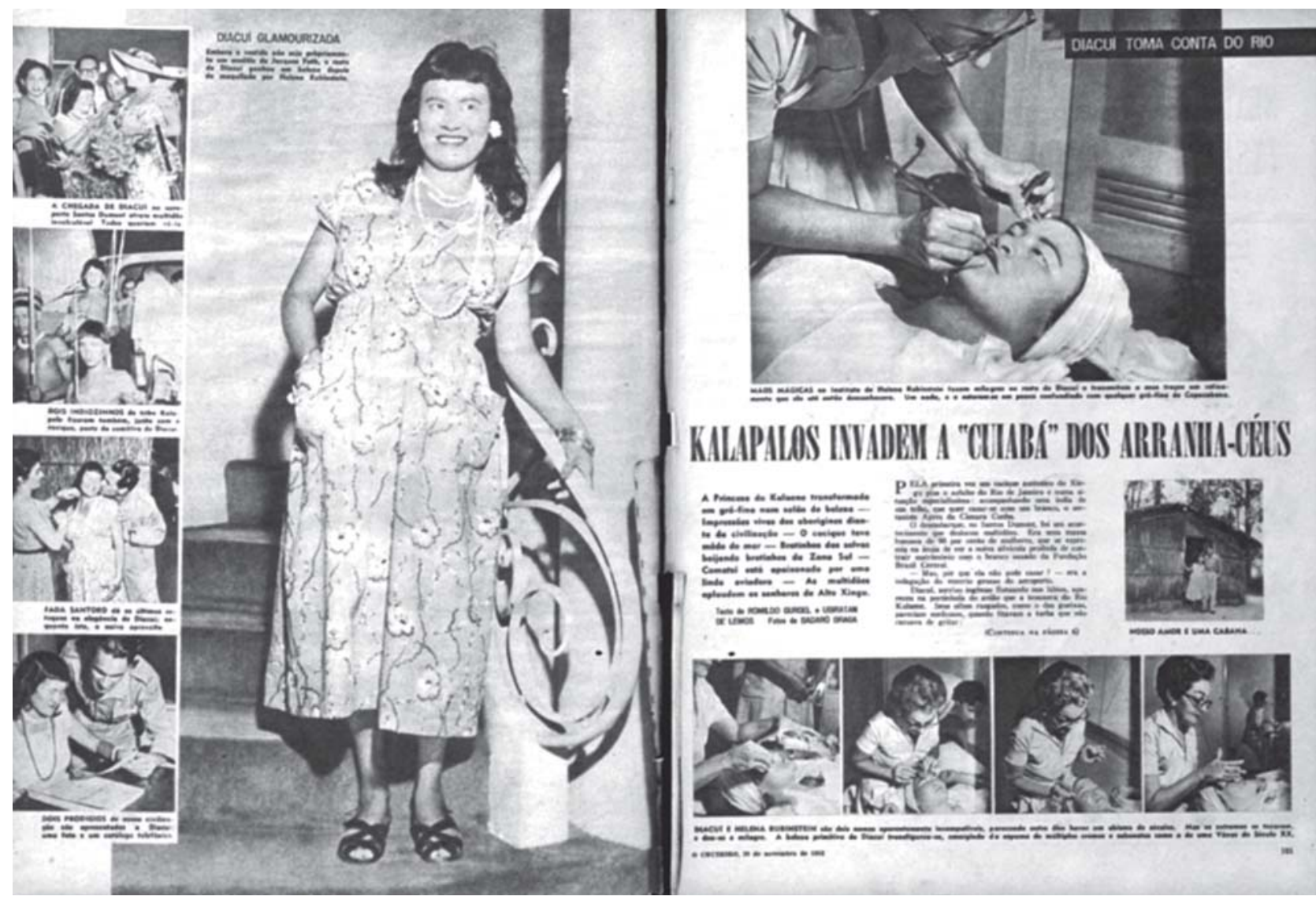

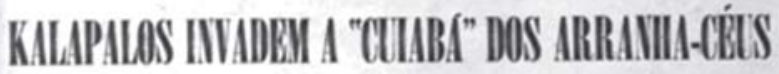
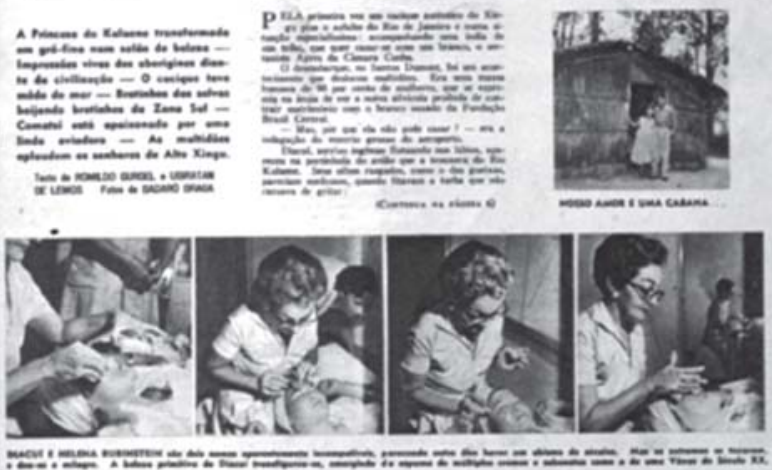

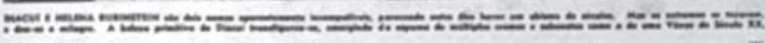

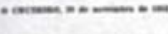



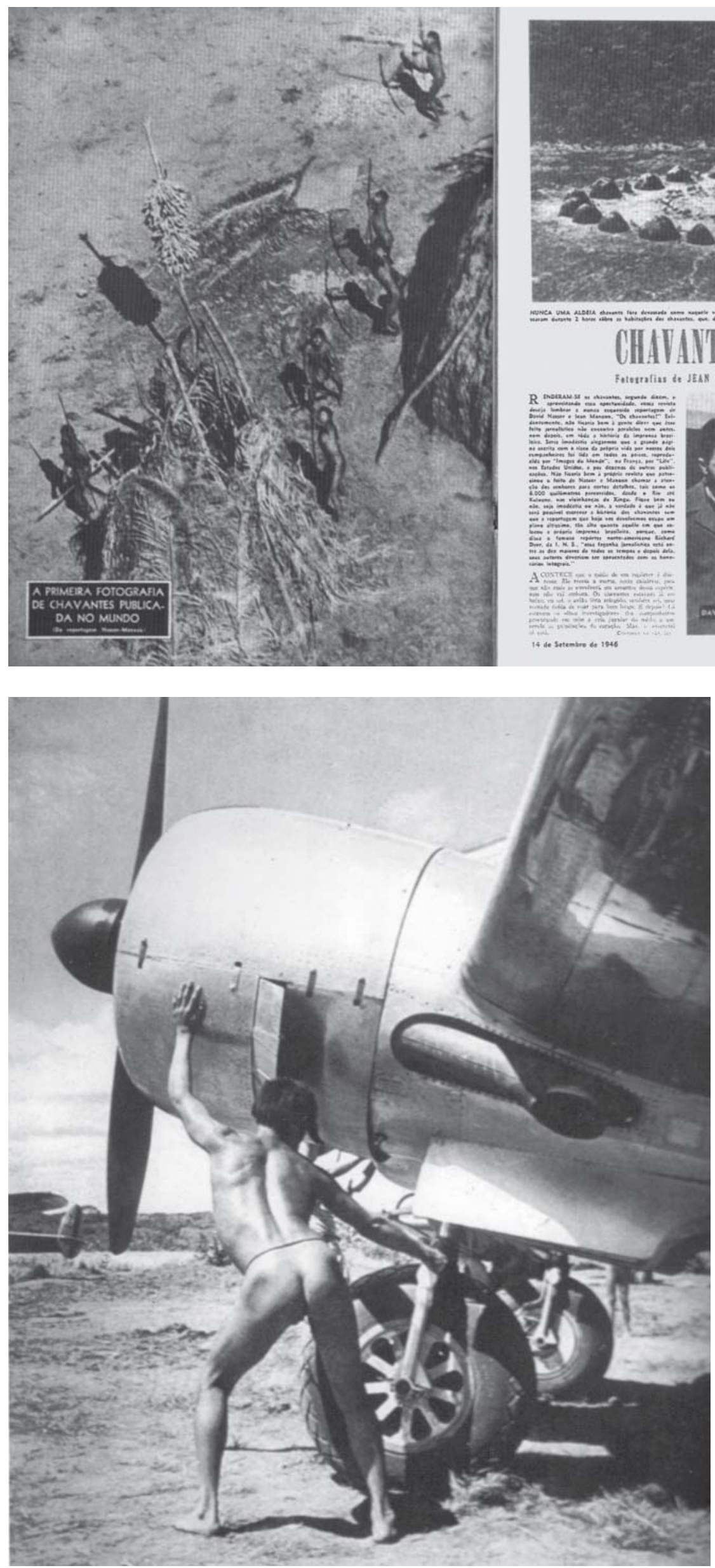

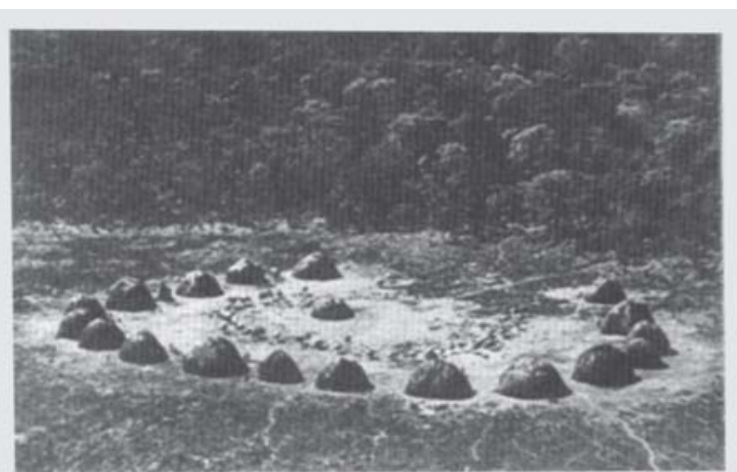

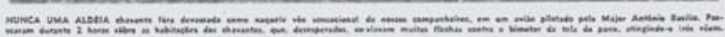
CHAVIVTES II GLERR

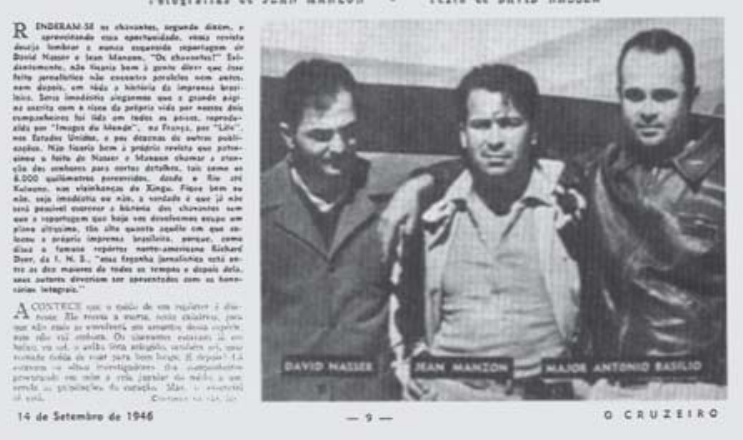

Figura 23: Índios xavante, 1946, foto de Jean

Manzon, coleção Revista o Cruzeiro (Museu de

Comunicação Social

Hipólito da Costa)

Figura 24: Índio

yawalapiti, Expedição

Xingu-Roncador, 1949,

foto de José Medeiros

(Acervo Instituto

Moreira Salles) 


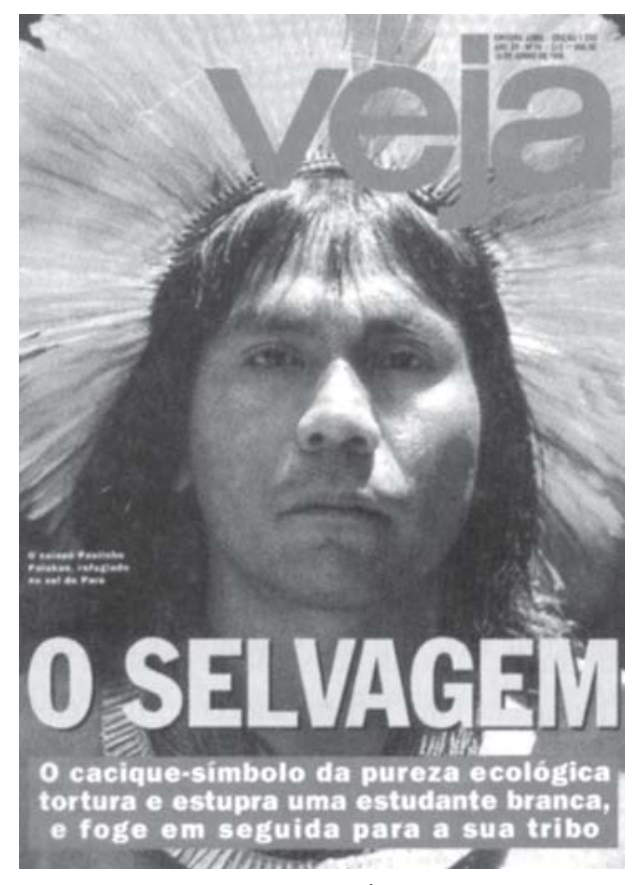

Figura 25: Capa da revista Veja, 10 jun. 1992, em que foi publicada a matéria "O selvagem" induzia o leitor a uma ambiguidade perversa, permitindo entender que o estupro seria natural da condição 'primitiva' (Macllum, 2001). Paulinho Paiacã era uma liderança ecológica, com reconhecimento internacional, e a reportagem foi publicada em plenos ventos da ECO 92, no Rio de Janeiro. A chamada de capa foi sensacionalista: "O SELVAGEM - Cacique-símbolo da pureza ecológica tortura e estupra uma estudante branca e foje em seguida para sua tribo" (O selvagem..., 10 jun. 1992). Vê-se, então, que ainda ao final do século XX a imprensa alimentava o imaginário nacional com a ideia de uma presença 'selvagem' como valor moral, entre os indígenas brasileiros.

\section{Claudia Andujar: entre o mágico e o etnográfico}

Claudia Andujar é um exemplo de obra fotográfica diferenciada, realizada ao final do século XX, que adentra um campo situado entre as artes visuais e o etnográfico. Sua inserção principal deu-se com a obtenção de duas bolsas de trabalho na Fundação Guggenheim, de Nova

York, para uma pesquisa fotográfica sobre o grupo indígena Yanomani, entre 1972 e 1974. Como resultado, publicou o livro Yanomami: frente ao eterno (Andujar, 1978), composto de 38 fotografias em preto e branco com intensos jogos de luz e sombra, retratos que ultrapassam a mera descrição e remetem a uma relação atemporal dos índios, uma busca de intensidades interiores para além da fotografia documental. Suas fotos participaram e foram a face midiática das ações da Comissão de Criação do Parque Yanomani (Comissão Pró-Índio), que lançou o livro Genocídio do Yanomami: morte do Brasil (1988). As imagens, com sons captados em campo, se tornaram um fotofilme pelas mãos de Marcelo Tassara, Povo do Sangue, Povo da Lua (1988), marcante pela intensidade de luz nas fotos de Andujar e pela denúncia das condições de vida dos Yanomami após o contato com garimpeiros e com trabalhadores da estrada aberta no habitat do grupo. O filme tem vida própria, com as fotografias ganhando animação, e ao chegar à televisão tornou-se forte instrumento de conscientização sobre a importância da reserva Yanomani. Não somente uma fotografia bruta e cruel das condições de vida decadente nos agita a alma, mas também as luzes que podem ser os elementos da vida.

Em 1998, Claudia Andujar participou da 2a Bienal Internacional de Fotografia de Curitiba, onde organizou parte importante de seu material sobre os Yanomami em três sessões centrais: a casa, a floresta e o invisível. Suas fotografias nos permitem experimentar o invisível, em que a luz fotográfica encontra a luz cintilante dos espíritos. Os feiticeiros evocam o sobrenatural, ao passo que a fotógrafa evoca a nova magia da imagem técnica anunciada por Vilém Flusser. O referente não é aderido à imagem fotográfica pelo fato de ser uma construção simbólica; perde sua carga mítica original descontextualizando o evento 
religioso, para transformar-se em outra magia, uma magia contemporânea que não se propõe a modificar o mundo e sim nossos conceitos sobre ele, o que Flusser (1980) denomina magia de segunda ordem. Em artigo sobre a trajetória de Claudia Andujar, Rogério Duarte (2003) assim se expressa sobre a fricção entre o fotográfico e o ritualístico:

Os espíritos auxiliares dos xamãs Yanomami, chamados xapiripë ou hekurapë, aparecem primeiramente a quem os invoca na forma de luzes cintilantes. Aos poucos revelam seus corpos minúsculos e brilhantes, enfeitados com plumas brancas na cabeça e braçadeiras de penas de arara e papagaio. Nesse universo, a luz assume uma densidade simbólica que somada à especificidade da linguagem fotográfica - luz e sombra - permite a expressão de um pensamento interior. Dessa forma, Claudia não fotografa "a luz", mas a cultura, ou ainda, os espíritos Yanomami. Em seu trabalho, é principalmente o diálogo entre a luz "material" e a luz "simbólica" que produz o resultado fotográfico.

Figura 26:

Wakata-ú,

Roraima, 1974, foto de Claudia Andujar

(Andujar, 2005)

Figura 27: Xamã, Wakata-ú,

Roraima, 1974, foto de Claudia Andujar

(Andujar, 2005)

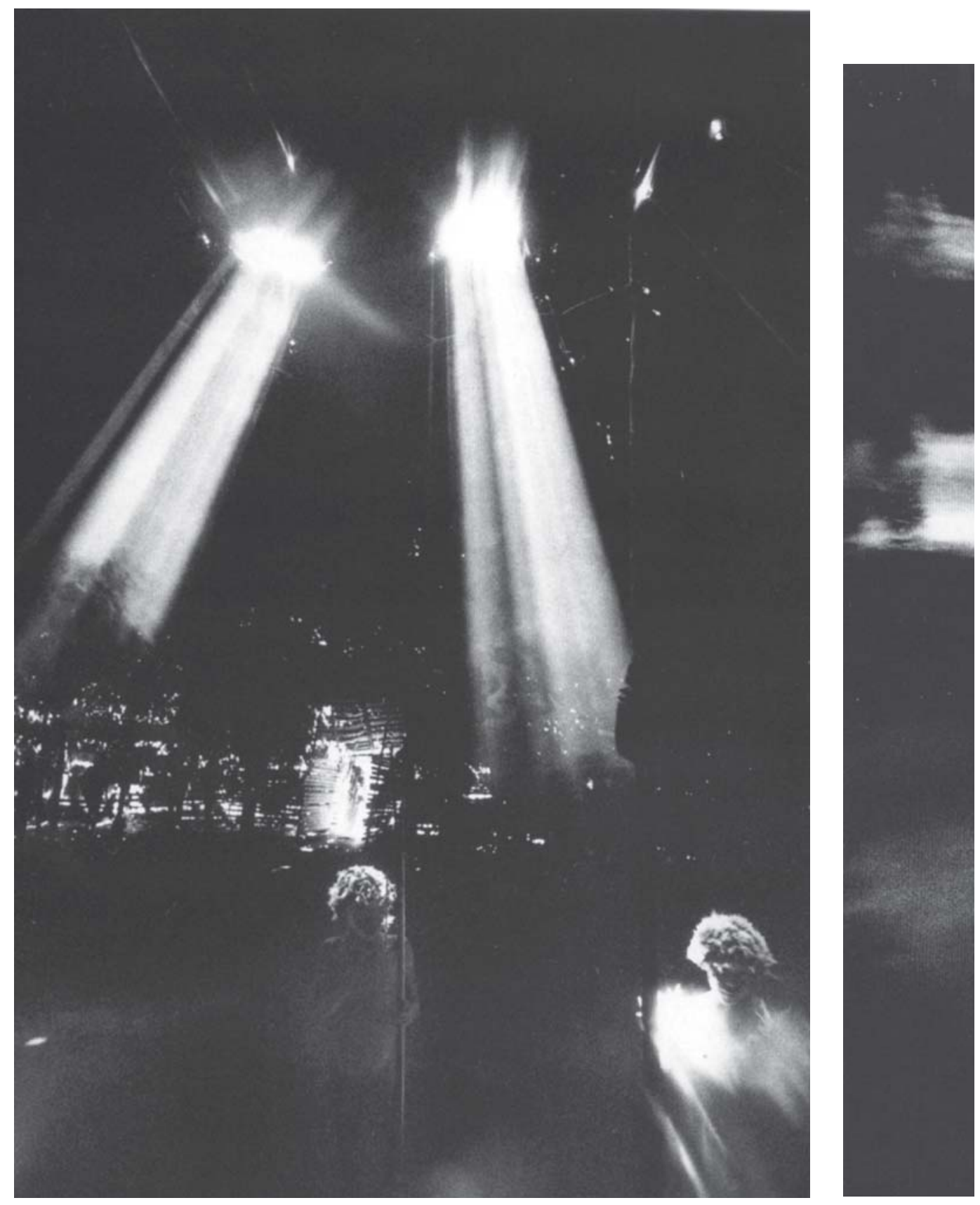


Claudia participou da 24a Bienal de São Paulo, em 1998, com fotomontagens de suas imagens que justapõem retratos e luzes e nas quais o elemento humano se desgarra de uma existência indicial do fotográfico e persiste um universo mágico, podemos dizer onírico, para nossos olhos. Claudia Andujar prenuncia desenvolvimentos posteriores no campo fotográfico sobre o índio, ao quebrar estruturas modeladores de nossa forma de ver pautadas em padrões positivistas da arte de descrever fotograficamente - e incluir a possibilidade de subjetividade e autoria. Encontramos um lugar teórico importante desse fazer em anos recentes, como nos indica Carlos Brandão (2004, p.52) quando conceitua um novo campo, uma etnopoética da imagem: "Antes de vir a ser um 'objeto útil' de leitura ou 'um meio para' alguma coisa na prática da antropologia, a fotografia é um momento de descobertas e de trocas de sensibilidades à volta da imagem. À volta de uma imagem. Tanto na vida cotidiana quanto em uma situação docente, a fotografia deveria ser algo pertencente ao intervalo entre o sentido e o encantamento...".

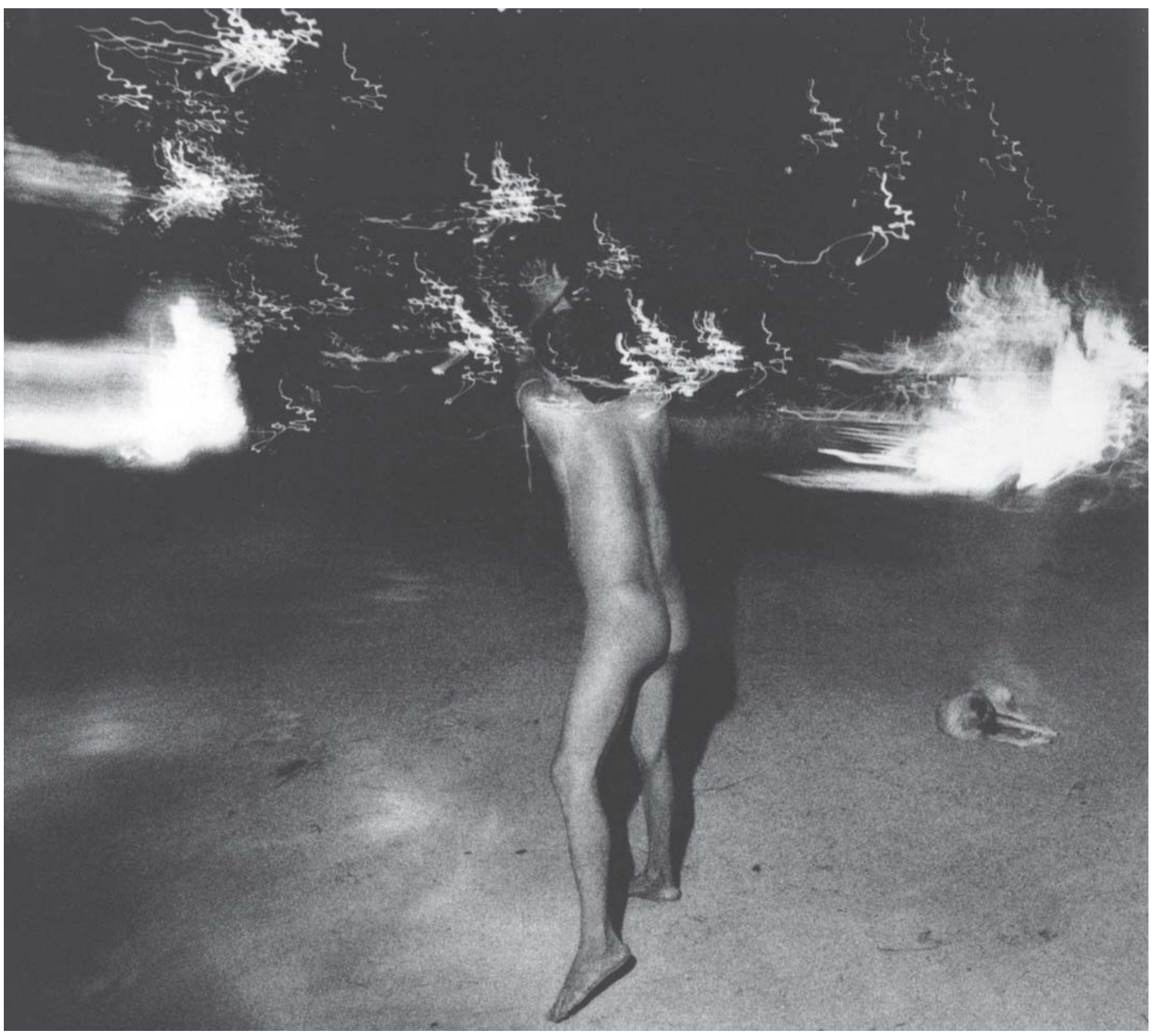


A ideia de encantamento traduz nossa aproximação sensitiva com as imagens de Claudia Andujar, quando o fotográfico, por suas características técnicas, nos apresenta, ou no induz a perceber, elementos mágicos presentes nos rituais, que não nos são dados a ver por não pertencermos à cultura Yanomami. Ao apresentar-nos a possibilidade do invisível, a fotografia assume outra função, a de magicizar nosso deslumbramento com as luzes imanentes do sobrenatural.

Mesmo sabendo, hoje, que a fotografia não pode fotografar os espíritos, como pensavam ainda no século XIX, nos deixamos levar pela experiência e ilusão estética como forma de compreensão do outro. Dentro de um campo fenomenológico, Claudia Andujar cria um novo espaço imagético, ao nos propor uma imagem-conceito do índio yanomani. Em pesquisa recente (Tacca, 2009), buscando compreender a questão da fotografia de rituais especificamente aquelas de um ritual de passagem -, sugiro um caminho conceitual acerca dessa espécie de fricção entre fotógrafo e campo mítico, na qual o fotógrafo, ao final, substitui os xamãs, criando uma nova ordem imagética e programática na sociedade de consumo de imagens que as torna mercadorias simbólicas.

\begin{abstract}
A existência de dois campos marginais, ou liminares, cria uma fricção ritualística entre o sagrado contextualizado na cosmologia religiosa e os mecanismos ideológicos no processamento da imagem técnica, ou seja, a metáfora de Turner para a modelagem do barro pela matéria nuclear, a transformação do pó, aplica-se à modelagem da luz pelos grãos de prata, uma construção imagética social que lhes dá forma existencial além da primeira realidade. A morte social encontra aqui similitude na morte da primeira realidade, já que prisioneira do recorte temporal e espacial do campo fotográfico ressurge na agregação como um conceito, uma imagem conceito (p.160).
\end{abstract}

Finalizando, podemos indicar três momentos importantes da construção da imagem do índio no Brasil, pelo campo da história da fotografia. No primeiro momento temos a ideia do exótico distante, lugar do selvagem próprio da natureza, ainda que domesticado, e um primeiro olhar etnográfico no final do século XIX, mas muito contaminado pelo exotismo. Em seguida, encontramos o encontro do nacional e o etnográfico da Comissão Rondon - com desdobramentos na produção da Secção de Estudos do SPI - e das narrativas fotojornalísticas da revista O Cruzeiro, na primeira metade do século XX. Por fim, incapacitada de ultrapassar o real sob a ontologia positivista, a fotografia etnográfica encontra no campo da arte um lugar para a elevação da imagem fotográfica como ilusão especular rumo ao mágico. Ao nos apresentar o invisível e o indizível, as luzes dos espíritos e o onírico, Claudia Andujar, ao menos assim, nos permite participar desse universo mítico. A separação entre o etnográfico e a possibilidade realística da fotografia, nas imagens de Claudia Andujar, revela uma poética sobre o outro muito distante do cerco imagético realístico da antropologia, e a ideia do índio tradicional ganha outra dimensão, agora contemplando a complexidade dessas culturas próprias.

Podemos ainda indicar uma nova possibilidade que se abre para a representação, embora ainda não muito visível, com o mundo digital, ou seja, uma produção fotográfica endógena, das próprias etnias e culturas, que conduz a práticas efetivas de identidade e, também, dá visibilidade a outros olhares distantes - e, nesses casos, a reafirmação do índio tradicional alimenta nosso imaginário, sedento dessas imagens míticas. 


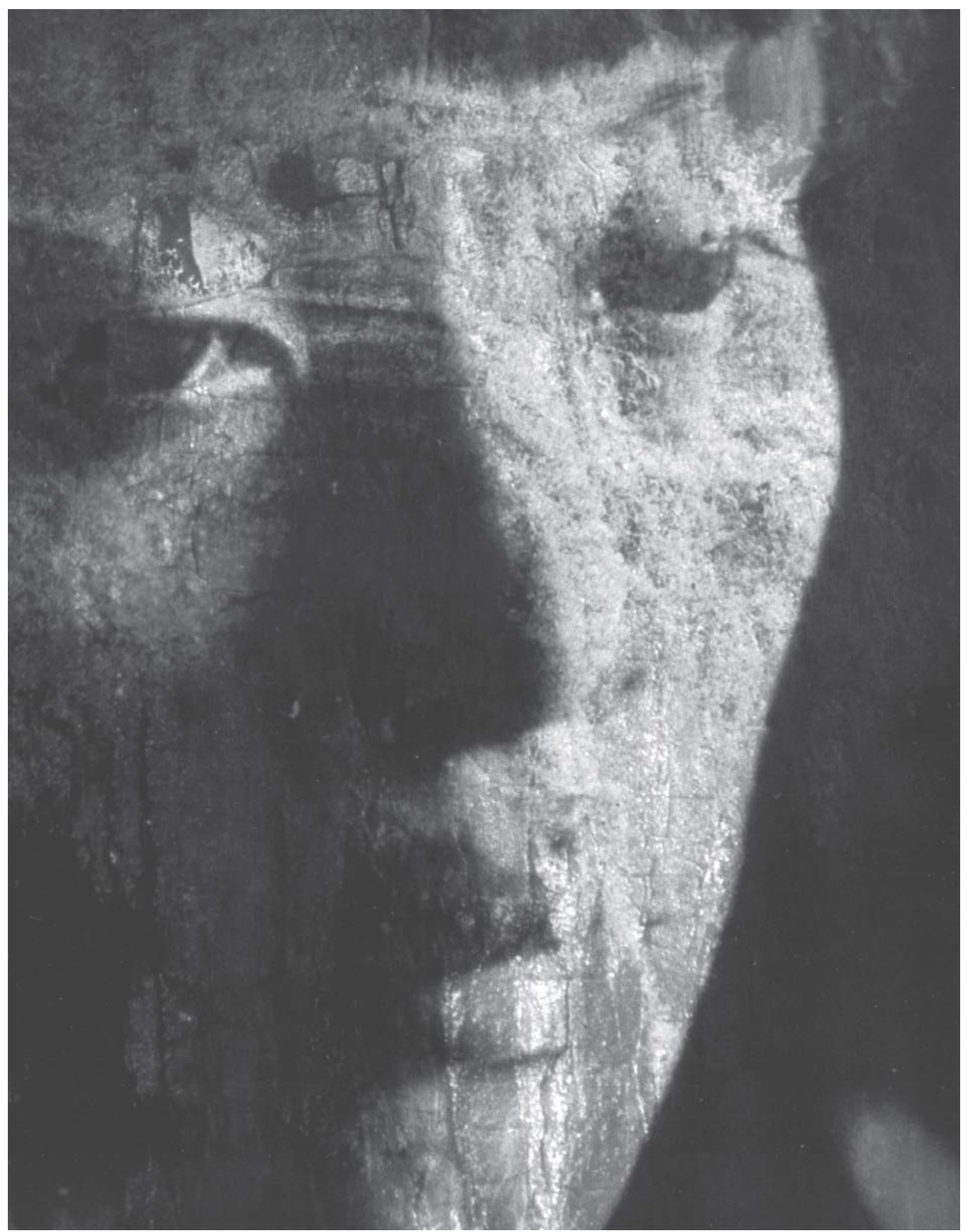

Figura 28: Fotomontagem sem título, da série Sonhos, 1974-2003, foto de Claudia Andujar (Andujar, 2005) 


\section{NOTA}

${ }^{1}$ Valentin (2009) analisa a produção fotográfica de Huebner e suas relações na sociedade manuara e sua dimensão científica da circulação das imagens na Europa.

\section{REFERÊNCIAS}

ANDUJAR, Claudia.

A vulnerabilidade do ser. São Paulo: Cosac Naify. 2005.

ANDUJAR, Claudia.

Genocídio do Yanomami: morte do Brasil,

São Paulo: Comissão pela Criação do Parque Yanomami, São Paulo. 1988.

ANDUJAR, Claudia.

Yanomami: frente ao eterno. São Paulo: Práxis. 1978.

BRANDÃO, Carlos.

Fotografar, documentar, dizer com a imagem. Cadernos de Antropologia e Imagem, Rio de Janeiro, n.18, p.27-54. 2004.

COSTA, Helouise.

Diacuí: a fotorreportagem como projeto etnocida. Studium, Campinas, n.17. Disponível em: http://www.studium.iar.unicamp.br/17/ 01.html. Acesso em: 5 out 2010. 2004.

DOBAL, Suzana.

Ciência e exotismo: os índios na fotografia brasileira do século XIX. Cadernos de Antropologia e Imagem, Rio de Janeiro, n.12, p.67-86. 2001.

DUARTE, Rogério.

Olhares do infinito: notas sobre a obra de Claudia Andujar. Studium, Campinas, n.12. Disponível em: http://www.studium.iar. unicamp.br/12/5.html. Acesso em: 30 set. 2010. 2003.

FLUSSER, Vilém

Filosofia da caixa-preta: ensaios para uma futura filosofia da fotografia. São Paulo: Hucitec. 1985.

KOSSOY, Boris.

Dicionário histórico-fotográfico brasileiro: fotógrafos e ofícios da fotografia no Brasil (1833-1910). São Paulo: Instituto Moreira Salles. 2002.

MACLLUM, Cecília.

O 'Paikan' da Veja: mídia, modernismo e a imagem do índio no Brasil. Cadernos de Antropologia e Imagem, Rio de Janeiro, n.12, p.19-38. 2001.

MOREL, Marco.

Imagens aprisionadas e resistência indígena: os daguerreótipos de 1844. Studium, Campinas, n.10. Disponível em: http://www.studium.iar. unicamp.br/10/7.html. Acesso em: 5 out. 2010. 2002.

\section{MUSEU DO ÍNDIO.}

Base de dados. Disponível em: http:// base2.museudoindio.gov.br/cgi-bin/ wxis.exe?IsisScript=phl82.xis\&cipar=phl82.cip \&lang=por. Acesso em: 26 set. 2010. s.d.

NIMUENDAJÚ, Curt.

Mapa etno-histórico de Curt Nimuendajú. Rio de Janeiro: IBGE; Fundação Pró-Memória. 1981.

NOVAES, Sylvia Caiuby.

Jogo de espelhos. São Paulo: EdUSP. 1993.

O SELVAGEM...

O selvagem: cacique-símbolo da pureza ecologia tortura e estupra uma estudante branca e foje em seguida para sua tribo. Veja, São Paulo, n.1238, p.68-73. 10 jun. 1992.

RIBEIRO, Darcy.

Diários índios: os Urubus-Kaapor. São Paulo: Companhia da Letras. 1996.

RONDON, Cândido Mariano Silva. Índios do Brasil: norte do rio Amazonas. Rio de Janeiro: Ministério da Agricultura, Conselho Nacional de Proteção aos Índios. v.3. (Publicação n.99). 1956.

RONDON, Cândido Mariano Silva. Índios do Brasil: cabeceiras do Xingu/rio Araguaia e Oiapóque. Rio de Janeiro: Ministério da Agricultura, Conselho Nacional de Proteção aos Índios. v.2. (Publicação n.98). 1953.

RONDON, Cândido Mariano Silva. Índios do Brasil: do centro ao noroeste e sul de Mato Grosso. Rio de Janeiro: Ministério da Agricultura, Conselho Nacional de Proteção aos Índios. (Publicação n.97). 1946.

SAMAIN, Etienne.

'Ver' e 'dizer' na tradição etnográfica: Bronislau Malinowski e a fotografia. Horizontes Antropológicos, Porto Alegre, ano 1, n.2, p.23-60. 1995.

SANTOS, Sílvio Coelho dos. Os índios Xokleng: memória visual. Florianópolis: Editora da UFSC. 1997. 
TACCA, Fernando de.

Antropologia e imagens em rede: a periferia na Internet. In: Sel, Susana (Comp.). La

comunicación mediatizada: hegemonías, alternatividades, soberanías. Buenos Aires: Consejo Latinoamericano de Ciencias Sociales (Clacso). 2009.

TACCA, Fernando de.

A amplitude cinematográfica de Luiz Thomaz Reis. Cadernos de Antropologia e Imagem, Rio de Janeiro, v.20, p.97-110. 2005.

VALENTIN, Andreas.

Os 'Indianer' na fotografia amazônica de

George Huebner (1885-1910). Tese

(Doutorado) - Programa de Pós-graduação em
História Social, Universidade Federal do Rio de Janeiro, Rio de Janeiro. 2009.

VASQUEZ, Pedro Karp.

Fotógrafos alemães no Brasil no século XIX.

São Paulo: Metalivros. 2000.

WEBB, Virginia-Lee.

Manipulated imagens: European photographs of Pacific peoples. In: Barkan, Elazar; Bush, Ronald (Ed.). Prehistories of the future: the primitivist project and the culture of modernism. California: Stanford University Press. p.175-201. 1995. 